6. ZNANSTVENA

KONFERENCA

NOVE PARADIGME

ORGANIZACIJSKIH

\title{
TEORIJ
}

\section{ZBORNIK POVZETKOV}

$18 \cdot$ MAREC $\cdot 2021$

\section{RAZISKOVANJE IN OBVLADOVANJE SPREMEMB}




\section{6. znanstvena konferenca}

Nove paradigme organizacijskih teorij 2021

z naslovom

\section{Raziskovanje in obvladovanje sprememb}


DOI: 10.37886/npot2021

\section{Raziskovanje in obvladovanje sprememb}

zbornik povzetkov

Urednik:

Prof. dr. Boris Bukovec

Založila: Fakulteta za organizacijske študije v Novem mestu Copyright (C) 2021 po delih in v celoti avtor in Fakulteta za organizacijske študije v Novem mestu, Novo mesto.

Vse pravice pridržane. Nobenega dela tega gradiva ni dovoljeno kopirati ali reproducirati v kakršnikoli obliki, vključujoč (ne, da bi bilo omejeno na) fotokopiranje, skeniranje, snemanje, prepisovanje brez pisnega dovoljenja avtorja ali druge fizične ali pravne osebe, na katero bi avtor prenesel materialne avtorske pravice.

E-dostop: https://www.fos-unm.si/si/dejavnosti/npot/objave/ DOI: $10.37886 /$ npot2021

Kataložni zapis o publikaciji (CIP) pripravili v Narodni in univerzitetni knjižnici v Ljubljani 


\section{Vsebina}

Kovčing v organizaciji v post COVID-19

doc. dr. Tatjana Dragović

Modeliranje odličnosti, suverenosti, državotvornosti in blagostanja

»Naše korenine naša prihodnost «

doc. dr. Marija Turnšek Mikačić, doc. dr. Tit Turnšek.....................................9

Strateške dileme in alternativne usmeritve neprofitnih športnih klubov doc. dddr. Igor Ivašković ................................................................. 14

Samo-ocena usvojenih kompetenc po končanem visokošolskem študiju

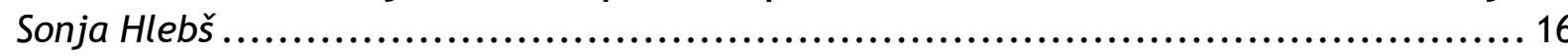

Načela menedžmenta sistemov kakovosti kot gradniki uspešnosti gospodarskih družb

Stojan Črv, prof. dr. Mirko Markič.

Komunikacijske kompetence $v$ terciarnem e-izobraževanju

mag. Monja Pust, prof. Dr (PhD, ZDA) Annmarie Gorenc Zoran

Modeli zrelosti menedžmenta projektov in poslovna uspešnost pri

prijavi na javne razpise

Tinkara Primožič, prof. dr. Mirko Markič.

Objektivni postopek segmentacije dobaviteljev ali blagovnih skupin $v$ Kraljičevo matriko

Božidar Lenarčič .....

Gradniki modela kakovosti delovnega življenja med slovenskimi zdravniki in vpliv na pripadnost organizaciji

Tea Šikovec

Izzivi obvladovanja sprememb v laboratorijih

doc. dr. Milan Simončič.

Vloga zunanjega svetovalca pri uvajanju organizacijskih sprememb v procesu proizvajanja

Idriz Selimović, prof. dr. Mirko Markič.

Ključni dejavniki digitalizacije procesov v oskrbni verigi

Andrej Lukan...

Kazalniki kakovosti farmacevtske skrbi ob hipertenziji

Breda Drenek Sotošek 50 
Analiza hudih telesnih poškodb v cestnem prometu in vloga urgentnega centra

Nataša Šporčić, doc. dr. Franc Brcar

Sistematični pregled raziskav na FOŠ

doc. dr. Franc Brcar...

Povezanost med gradniki organizacijske energije in avtopoietičnimi lastnostmi

mag. Mari Božič, prof. Dr (PhD, ZDA) Annmarie Gorenc Zoran

Vpliv dinamičnega poslovnega okolja na temeljno strategijo podjetja Sabina Veršič

Napoved vrednosti trga obstoječih in prihajajočih tehnoloških sprememb

doc. dr. Tine Bertoncel, prof. dr. Maja Meško .66 


\title{
Kovčing v organizaciji v post COVID-19
}

\author{
Tatjana Dragovič* \\ University of Cambridge, Faculty of Education, United Kingdom \\ Fakulteta za organizacijske študije v Novem mestu \\ td344@cam.ac.uk
}

Raziskovalno vprašanje (RV): Kako so organizacije v Sloveniji in tujini (VB in ZDA) uporabljale kovčing v letu 2020 v času COVID-19 in kaj so se med uporabo naučile za post-COVID obdobje? Namen: Namen raziskave je bil prvo preučiti načine uporabe kovčinga $v$ poslovnih organizacijah (v času COVID-19), ki so že prej poznale in ponujale kovčing svojim zapolenim. Drugi namen je bil oblikovati napotke za uporabo kovčinga za naslednje obdobje (post-COVID 19) na osnovi pridobljenih vpogledov v letu 2020. Zaradi prehoda na »delo od doma« je bilo potrebno najprej posebej raziskati, v kateri obliki se je kovčing uporabljal $v$ novonastalih okoliščinah in kako so se zaposleni odzivali.

Metoda: Po pregledu najnovejše literature (iz leta 2020 in 2021) na področju uporabe kovčinga v poslovnih organizacijah $v$ času COVID-19, se je kvalitativna raziskva nadaljevala z zbiranjem podatkov skozi 10 intervjujev, in sicer 6 intervjujev z vodilnimi iz slovenskih organizacij in 4 z vodilnimi iz tujih organizacij iz Velike Britanije in Združenih državah Amerike. Intervjuvanci prihajajo iz 8 različnih organizacij (4 iz Slovenije in 4 iz tujine). Intervjuji so bili analizirani s pomočjo »Interpretative Phenomenological Analysis (IPA)«.

Rezultati: Raziskava je pokazala, da se je kovčing $v$ času COVID-19 in dela od doma v treh organizacijah uporabljal "parcialno« oziroma le kot orodje pri vodenju, medtem ko se je v preostalih petih organizacijah uporabljal »holistično" oziroma kot »drža» in »miselnost» in imel pozitiven vpliv na »wellbeing zaposlenih. Čeprav so organizacije v praksi »holistični« pristop izvajale različno, je bil skupen element prehod od takoimenovanega »first generation coaching " ( $z$ močno ciljno naravnanostjo) k »third generation coaching « ( $z$ močno dialoško in reflektivno naravnanostjo).

Organizacija: Organizacije, ki že uporabljajo kovčing, lahko nadgradijo in mogoče celo preoblikujejo način izvajanja kovčinga v obdobju post-COVID. „Parcijalna« uporaba kovčinga se lahko razširi na sistemki pristop in s tem na učinke, ki presegajo le ciljno naravnanost.

Družba: Prispevek družbi se odraža v novi »holitični« uporabi kovčinga v organizacijah, ki ima za posledico višjo "wellbeing" raven zaposlenih.

Originalnost: Izvedena raziskava predstavlja prispevek k novim pristopom za izboljšanje "wellbeing " zaposlenih v obdobju post-COVID skozi kovčing in tako poziva na uporabo dobrih praks v času COVID 19. 
Omejitve/nadaljnje raziskovanje: Raziskava je bila omejena na le 8 organizacij in 10 vodilnih in bi jo bilo zaželeno razširiti na večje število organizacij udeležencev. Raziskava se je ukvarjala le z vpogledi iz uporabe kovčinga v času COVID-19. Na »wellbeing zaposlenih je lahko vplivalo veliko drugih dejavnikov, ki bi lahko bili predemt nadaljnjih raziskav.

Ključne besede: kovčing, COVID-19, kovčing v organizacijah, "first generation coaching", "third generation coaching".

Tatjana Dragovič je magistrirala in doktorirala $v$ Veliki Britaniji na področju izobraževanja odraslih in na podpodročjih prenosa znanja in profesionalnega razvoja zaposlenih. Od leta 2007 poučuje in raziskuje na Univerzi v Cambridgu, Velika Britanija na področjih izobraževanja, dialoškega pristopa, vodenja, coachinga, raziskovalnh metod za »practice research«. Od leta 2015 na Univerzi v Cambridgu poučuje doktorante kvalitativne raziskovalne metode in vodi raziskovalno skupino »Leadership, Educational Improvement and Development (LEID)«. Raziskovalno se ukvarja s proučevanjem razvoja voditeljstva, profesionalne identitete, dialoških pristopov, možnostnega mišljenja, coachinga in profesionalnega razvoja zaposlenih. Na Fakulteti za organizacijske študije $v$ Novem mestu je bila izvoljena v naziv docentke.

\section{Post COVID-19 Coaching in Organisations}

Research Question (RQ): How did organizations in Slovenia and abroad (UK and USA) utilise coaching in 2020 during COVID-19 and what are the lessons learned for the post-COVID period?

Purpose: The purpose of the research was to first examine the ways of using coaching in those organizations (during COVID-19) that were offering coaching to their employees even before COVID-19. The second purpose was to develop guidelines for the use of coaching for the postCOVID 19 times based on the insights gained in 2020. Due to the transition to "work from home", it was necessary to first investigate in what way coaching was used in the new circumstances as well as employees' responses.

Method: After reviewing the most recent literature (from 2020 and 2021) in the field of coaching in organizations during COVID-19, the qualitative research continued with data collection through 10 interviews (6 interviews with leaders from Slovenian organizations and 4 with leaders from foreign organizations from the United Kingdom and the United States). Interviewees come from 8 different organizations (4 from Slovenia and 4 from abroad). Interviews were analysed using the Interpretative Phenomenological Analysis (IPA). 
Results: Research has shown that coaching was used "partially" or through a piecemeal approach i.e. only as a management/leadership tool in three organizations during COVID-19 (work from home) while in the remaining five organizations used it "holistically" or as an "attitude" and "mindset" and as such had a positive impact on employees' wellbeing. Although organizations practiced a "holistic" approach differently, the common feature was the transition from so-called "first generation coaching" (with a strong goal orientation) to "third generation coaching" (with a strong dialogical and reflective orientation).

Organization: Organizations already using coaching can upgrade and perhaps even reshape the way coaching is conducted in the post-COVID period. The "partial/piecemeal" use of coaching can be extended to a systematic approach and thus bring effects that transcend goalorientation.

Society: The contribution to society is reflected in the new "holistic" use of coaching in organizations, which results in a higher "wellbeing" level of employees.

Originality: The research contributes to new approaches to improving the "wellbeing" of employees in the post-COVID period through coaching.

Limitations / further research: The research was limited to only 8 organizations and 10 leaders and it would be desirable to extend it to a larger number of organizations and participants. The research dealt only with insights from the use of coaching during COVID-19. The "wellbeing" of employees could be influenced by many other factors that could be the subject of further research.

Keywords: coaching, COVID-19, coaching in organisations, "first generation coaching", "third generation coaching».

Tatjana Dragovic has obtained a master and Doctorate degree in Education (EdD) in Great Britain in the fields of adult education, knowledge transfer, professional identity and continuing professional development. Since 2007, she has been affiliated with the University of Cambridge, UK in teaching and researching roles in education, dialogic approach, leadership, coaching and research methods for practice research. In addition, Dr Dragovic has also been teaching qualitative research methods for doctoral (EdD) students and leading research community »Leadership, Educational Improvement and Development (LEID) « at University of Cambridge since 2015. Her research interest lies in the fields of leadership development, professional identity, dialogic approaches, creativity, possibility thinking, coaching, continuous improvement and professional development. She holds assistant professorship at the Faculty of Organizational Studies in Novo mesto. 


\title{
Modeliranje odličnosti, suverenosti, državotvornosti in blagostanja »Naše korenine naša prihodnost«
}

\author{
Marija Turnšek Mikačić \\ Fakulteta za organizacijske študije v Novem mestu \\ mikacic2007@gmail.com
}

\section{Tit Turnšek}

Fakulteta za organizacijske študije $v$ Novem mestu titturnsek@ymail.com

Raziskovalno vprašanje (RV): Raziskava predstavlja modeliranje procesa izražanja odličnosti, suverenosti, državotvornosti in blagostanja naroda, z namenom, da bi slovenski narod skozi svojo identiteto, tako kot je $v$ davni preteklosti znal ohraniti svoj jezik in suverenost, tudi danes $v$ samostojni državi Sloveniji znal suvereno in državotvorno sodelovati pri vodenju lastne države in ustvarjalno sodelovati z drugimi narodi. Vprašali smo se: Ali deluje odličnost znamenitih in uspešnih Slovencev in Slovenk in če deluje, bomo v okviru ravni modeliranja po R. Diltsu proučili vrednote in prepričanja, strategije in veščine, vedenje in okolje in izrazili notranjo gotovost, da je takšen model izražanja odličnosti in blagostanja razviden.

Namen: Splošni namen raziskovanja je odgovoriti na vprašanje: Kako je mogoče izboljšati zavedanje Slovencev o lastni odličnosti? Zavest o lastni odličnosti, ki temelji na odličnosti znamenitih in uspešnih Slovencev in Slovenk, pomaga Slovencem v novi državi pri nadaljnjem gospodarskem in kulturnem razvoju in pri ohranjanju in uveljavljanju suverenosti in enakopravnosti pri sodelovanju z drugimi državami in narodi.

Metoda: Kako dosežemo cilje raziskave, uporabljene metode in teoretični pristop. Modeliranje okolja, vedenja, strategij, prepričanj, vrednot in identitete Karantancev ob dogodku ustoličevanja njihovih knezov od 6. stoletja dalje, njihovih simbolov (Sveta Hema, knežji kamen) do modeliranja Koroških Slovencev (Andrej Šturm, dr. Jože Kopeinig), in njihove odličnosti danes ter modeliranje priznanih Slovencev (pisatelj Drago Jančar) in uspešnih Slovenk (M. Š., M. B.), nam predstavlja osnovo za spoznanje vedenjskih vzorcev odličnosti in blagostanja na osnovi metodologije modeliranja pri nevrolingvističnem programiranju.

Rezultati: Kratek opis rezultatov raziskave. Cluster mikro odličnosti znamenitih in uspešnih Slovencev in Slovenk, pri ohranjanju suverenosti in neodvisnosti smo ga razčlenili v okviru naslednje klasifikacije: 
- Strateško mišljenje za doseganje ciljev odličnosti, suverenosti, državotvornosti in blagostanja. pomeni sposobnost uvida v njihovo uresničitev, skozi časovno črto lastne zgodovine.

- Socialna kompetenca kot sposobnost razumeti druge ljudi in narode, jih motivirati in z njimi komunicirati.

- Samopodoba vsebuje stanje, uravnavanje, kriterije, strategije odličnosti in izbira kaj je najbolj primerno $v$ dani situaciji. Samopodoba je celota procesov za vodenje odličnosti.

- Sposobnost sistematičnega načina mišljenja je pri odličnosti popoln in zanesljiv znak zrelosti človeka in naroda.

Med razpravo o tem, kaj pravzaprav odličnost je, se je za državotvornost, suverenost in odličnost kot eden ključnih oz. pomembnih dejavnikov pokazala ekonomska neodvisnost. Odsotnost le-te je $v$ kasnejših obdobjih slovenstva prav gotovo pogojevala vpliv drugih narodov na Slovence.

Organizacija: Kakšen je vpliv raziskave na menedžerje in organizacijo oz. prakso. Blagostanje neke skupnosti pomeni blaginjo posameznikov, ki to skupnost sestavljajo. Kar velja za večje sisteme (državo), velja tudi za njegove sestavne dele - podsisteme oz. manjše sisteme (državljane).

Družba: Kakšen je vpliv raziskave na družbo, socialno odgovornost in okolje. Pri raziskavi smo prišli do ideje blagostanja oz. izobilja. Pri tem smo imeli v mislih predvsem materialno blaginjo, ki pa je posledica duhovnega blagostanja.

Originalnost: Kaj je novega v raziskavi, kakšna je vrednost oz. originalnost raziskave: Koncept človekovega razvoja, kot je bil leta 2000 opredeljen v desetem svetovnem Poročilu o človekovem razvoju (Human Development Report), opozarja na pomen izpolnitve osnovnih socialnih, ekonomskih, kulturnih, civilnih in političnih pravic. Skrb za enakost pomeni središče človekovega razvoja. Opredeljuje pomen demokratizacije kot participacije državljanov pri vodenju države.

Omejitve/nadaljnje raziskovanje: Omejitve raziskave in predlogi za nadaljnje raziskovanje. Modeliranje odličnosti naroda, skupine ljudi in posameznikov ni zaključena celota. So dogodki v zgodovini naroda, ki so pomembno vplivali na odličnost, suverenost, državotvornost in blagostanje, še neobdelani in puščajo izzive za nadaljnje proučevanje.

Ključne besede: odličnost, demokracija, narod, nevrolingvistično programiranje, modeliranje, blagostanje, strateško mišljenje, socialna kompetenca.

Dr. Marija Turnšek Mikačić je doktorica znanosti in docentka menedžmenta kakovosti na Fakulteti za organizacijske študije FOŠ Novo mesto, univ. diplom. ekonomistka in mag. znanosti s področja poslovne politike in organizacije na Ekonomski fakulteti v Ljubljani, vodja službe za tržne raziskave in razvoj kozmetike v tovarni Lek, direktorica 
sektorja za plan in analize pri podjetju ČGP Delo, sekretarka zbora združenega dela Skupščine Republike Slovenije, sekretarka Državnega sveta Republike Slovenije. Predava na Fakulteti za organizacijske študije FOŠ Novo mesto, na Visoki šoli za upravljanje podeželja, Grm Novo mesto. Je NLP praktik ${ }^{\mathrm{TM}}$, NLP mojster praktik ${ }^{\mathrm{TM}}$, NLP trener INLPTA $^{\text {TM }}$, NLP coach $^{\text {TM }}$, vodi certificirano šolo NLP coachinga Transforma coaching team. avtorica knjige Karierno načrtovanje - kako najdeš v sebi skriti zaklad, vrste strokovnih člankov in publikacij.

Dr. Tit Turnšek je doktor znanosti in docent na Visoki šoli za upravljanje podeželja Novo mesto. Diplomiral je na Fakulteti za elektrotehniko Univerze v Ljubljani in absolviral podiplomski študij na Fakulteti za organizacijske vede Univerze Maribor. Doktoriral je na Fakulteti za organizacijske študije FOŠ Novo mesto. Delal je na razvojnih projektih na področju komunikacijskih tehnologij, bil je direktor družbe Iskra Elektrozveze d.d. V sredini sedemdesetih let je postal zunanji sodelavec Inštituta za sociologijo. Tu se je intenzivno ukvarjal s teorijo sistemov in sistemsko dinamiko ter njeno uporabnostjo pri proučevanju socio sistemov.

Leta 1998 je bil minister za obrambo Republike Slovenije in 2000 ambasador Republike Slovenije na Kitajskem. Izdal je knjigi Dinamika mednarodnih odnosov in Sistemska dinamika. Raziskuje in predava področje Populacijske dinamike. Je NLP praktik ${ }^{\mathrm{TM}}$, NLP mojster praktik ${ }^{\mathrm{TM}}$, NLP coach. Predava na šoli NLP coachinga Transforma coaching team. 



\section{Modelling Excellence, Sovereignty, Statehood and Prosperity: Our Roots Are Our Future}

Research Question (RQ): This research models the process of expressing excellence, sovereignty, statehood and prosperity of a nation with the intent of the Slovenian nation. It is done to use its identity, as it did to preserve the independent state of Slovenia's language and sovereignty in the past, to be able to collaborate in sovereignty and statehood, managing their country and creatively cooperating with other nations. We posed the following questions: Does the excellence of renowned and successful Slovenians function? If so, we will use the modelling level of R. Dilts to study the values and convictions, strategies and skills, behaviour and environment to express the internal assurance that such a model of expressing excellence and prosperity is indeed evident.

Purpose: How is it possible to improve the awareness of Slovenians on their own excellence? Awareness of own excellence, founded on the excellence of renowned and successful Slovenians, assists the Slovenians to further the economic and cultural development in their new country, and to preserve and establish sovereignty and equality in collaboration with other countries and nations.

Method: Modelling the environment, behaviour, strategies, convictions, values and identity of the Carantanians upon the event of ducal inauguration from the 6th century, their symbols (Saint Hema, Prince's Stone) to the modelling of the Carinthian Slovenians (Andrej Šturm, Dr. Jože Kopeinig) to their excellence today and modelling renowned Slovenians (author Drago Jančar) represents a basis of learning the behavioural patterns of excellence and prosperity based on modelling methodology in neurolinguistic programming.

Results: The cluster of micro excellence of renowned and successful Slovenians in preserving sovereignty and independence was distributed within the following classifications:

- Strategic mindset in reaching the objectives of excellence, sovereignty, statehood and prosperity means insight into realisation in the timeline of their own history.

- Social competence as the ability to understand other people and nations, which acts as motivation and communication.

- Self-image includes the condition, regulation, criteria, excellency strategies and a choice that is most suitable in the given situation. Self-image is a unity of processes for managing excellence.

- The ability of a systematic mindset is a perfect, reliable sign of maturity and nation in excellence.

Economic independence has been introduced as one of the key factors for statehood, sovereignty and excellence during the discussion what excellence truly is. The absence of this 
independence in the latter days of Slovenianhood has unquestionably conditioned the influence of other nations on Slovenians.

Organisation: Prosperity of a community means the prosperity of individuals, comprising this community. Whatever is applied to the larger system (country), shall be applied to its integral parts - subsystems or smaller symptoms.

Society: The research reached the concept of prosperity or abundance. This mostly applies to material prosperity as a consequence of spiritual prosperity.

Originality: The concept of the human development, as classified in the year 2000 in the 10th Human Development Report, emphasises the importance of fulfilling basic social, economic, cultural, civilian and political rights - equality being the centre of the human development. It defines the meaning of democracy as participation of the citizens in managing the country.

Limitations / Further Research: Modelling the excellence of the nation, a group of people and individuals is not an exclusive unity. The history of a nation speaks of events that had an important influence on excellency, sovereignty, statehood and prosperity.

Keywords: excellence, democracy, nation, neurolinguistic programming, modelling, prosperity, strategic mindset, social component.

Dr. Marija Turnšek Mikačić holds a Doctorate in Quality Management and acts as assistant professor at the Faculty of Organisation Studies (FOŠ) in Novo Mesto. She is a university graduate in Economics, she received her Master of Science degree in Business Policy and Organisation Sciences at the Faculty of Economics in Ljubljana; she is the head of the market research department and cosmetics development at the Lek pharmaceutical company, director of the planning and analysis sector at the ČGP Delo publishing company, secretary at the Board of a National Assembly of the Republic of Slovenia and secretary of the National Council of the Republic of Slovenia. She is a lecturer at the Faculty of Organisation Studies (FOŠ) in Novo Mesto and also a at the Landscape Governance College GRM in Novo Mesto. She is an NLP Practitioner ${ }^{\mathrm{TM}}$, NLP Master Practitioner ${ }^{\mathrm{TM}}$, NLP INLPTA Coach $^{\mathrm{TM}}$, NLP Coach ${ }^{\mathrm{TM}}$ and she manages a certified institution the NLP Coaching School Transforma Coaching Team; she is the author of Karierno načrtovanje - kako najdeš v sebi skriti zaklad (Career Planning - How To Find A Hidden Treasure Within) and numerous professional articles and publications.

Dr Tit Turnšek holds a doctorate and acts as assistant professor at the Landscape Governance Higher Education Institution Novo mesto. He graduated from the Faculty of Electrical Engineering at the University of Ljubljana and completed his undergraduate studies at the Faculty of Organisational Sciences at the University of Maribor. He received his Doctorate at the Faculty of the Organisational Studies (FOŠ) Novo mesto. Turnšek collaborated on development projects in the field of communication technologies. He acted as the Director at the Iskra Elektrozveze d.d. Company. In the middle of the 70s he was appointed an assistant at the Sociology Institute, where he intensively managed the system and system dynamics theory, and its usefulness in studying the socio systems. In 1998 he acted as the Minister of Defence of the Republic of Slovenia, and in 2000 he was appointed as the ambassador of the Republic of Slovenia in China. He published the books Dinamika mednarodnih odnosov (International Relations Dynamics) and SYSTEM DYNAMICS publication. He researches and lectures the field of Population Dynamics. He is NLP Practitioner ${ }^{\mathrm{TM}}$, NLP Master Practitioner ${ }^{\mathrm{TM}}$, NLP Coach $^{\mathrm{TM}}$, . He also lectures at the NLP Coaching School Transforma Coaching Team. 


\title{
Strateške dileme in alternativne usmeritve neprofitnih športnih klubov
}

\author{
Igor Ivašković \\ Ekonomska fakulteta Ljubljana \\ igor.ivaskovic@ef.uni-lj.si
}

Raziskovalno vprašanje (RV): Katere so ključne strateške odločitve, o katerih odločajo vodstva športnih klubov in katere strateške alternative so jim na voljo?

Namen: Namen prispevka je pomagati vodstvom neprofitnih športnih klubov pri identifikaciji ključnih strateških dilem in strateških alternativ, ki so na voljo tem organizacijam.

Metoda: Uporabljena sta SWOT analiza in Porterjev model pet silnic za analizo ekonomskih, političnih in drugih družbenih dejavnikov, ki so vplivali na športno industrijo na obravnavanem področju. Nato so s pregledom literature s področja poslovnih ved pojasnjene posebnosti procesa produkcije in identifikacijo treh ključnih strateških dilem.

Rezultati: Ugotovljene tri dileme so: a) fokus na tekmovalnih rezultatih ali na razvoju lokalne skupnosti, b) hitrejše doseganje ciljev ali manjša stopnja tveganja, c) zmanjševanje stroškov ali rast organizacije. Na podlagi različnih kombinacij članek na koncu predstavi pet temeljnih alternativnih usmeritev, in sicer: a) strateški fokus na športnih rezultatih, b) strategija anorganske rasti, c) strategija organske rasti, č) strategija razvoja okolja ter d) strategija povečevanja rezerv oz. preživetja.

Organizacija: Študija ponuja novo klasifikacijo strategij neprofitnih športnih klubov.

Družba: Študija poudarja pomen odnosa med športnimi klubi in lokalno skupnostjo in prikazuje, kako se ta odnos spreminja glede na izbrano strategijo.

Originalnost: Nova klasifikacija strateških alternativ. Prva raziskava o ključnih poslovnih odločitvah neprofitnih športnih klubov v Jugovzhodni Evropi.

Omejitve/nadaljnje raziskovanje: Priporočljive so nadaljnje raziskave med športnimi klubi skozi daljše časovno obdobje, v različnih okoljih in v različnih športnih panogah.

Ključne besede: športni klubi, neprofitne organizacije, tranzicija, strategije, poslovno odločanje.

Igor Ivašković je diplomiral iz prava, zgodovine, južnoslovanskih študijev, pedagogike in andragogike in ekonomije, doktoriral je iz prava, poslovnih ved in politologije ter je trenutno zaposlen na Ekonomski fakulteti Univerze v Ljubljani.

Bibliografija na strani: https://bib.cobiss.net/bibliographies/si/webBiblio/bib201_20210213_105819_34866.html 


\section{Strategic Dilemmas and Alternatives of Non- Profit Sports Clubs}

Research Question (RQ): What are the key strategic decisions made by sport club management and what strategic alternatives are available to them?

Purpose: The purpose is to help the management of non-profit sport clubs by identifying key strategic dilemmas and their strategic alternatives.

Method: The SWOT analysis and Porter's model of five forces are used for the analysis of economic, political and other social factors that influenced the sports industry in the field. Then, a review of the management literature is used for an explanation of the production process specifics and identification of three key strategic dilemmas.

Results: Three dilemmas identified are: a) the focus on sport results vs. the development of the local community, b) quick achievement of goals vs. reducing the level of risk, c) reduction of costs vs. organizational growth. Based on different combinations, the article presents five basic alternative orientations, namely: a) strategic focus on sports results, b) strategy of inorganic growth, c) strategy of organic growth, d) strategy of local community development, and e) strategy of increasing organizational reserves.

Organization: The study offers a new classification of strategies for non-profit sports clubs.

Society: The study emphasizes the importance of the relationship between sports clubs and the local community, and shows how this relationship changes according to the chosen strategy.

Originality: A new classification of strategic alternatives. The first survey on key business decisions of non-profit sports clubs in South-East Europe.

Limitations / further research: Further research between sports clubs over a long period of time, in different environments, and in different sport branches is recommended.

Keywords: sports clubs, non-profit organizations, transition, strategies, business decisions.

Igor Ivašković graduated in law, history, South Slavic studies, pedagogy and andragogy (educational studies), and economics, holds PhDs in law, business administration and political science, and is currently employed at the School of Economics and Business, University of Ljubljana.

Bibliography on page: https://bib.cobiss.net/bibliographies/si/webBiblio/bib201_20210213_105721_34866.html 


\section{Samo-ocena usvojenih kompetenc po končanem visokošolskem študiju}

\section{Sonja Hlebš}

Univerza $\vee$ Ljubljani, Zdravstvena fakulteta sonja.hlebs@zf.uni-lj.si

Raziskovalno vprašanje (RV): Kakšna je samo-ocena usvojenih kompetenc študentov po končanem visokošolskem študiju?

Namen: Namen naše raziskave je bil ugotoviti v kolikšni meri so študenti bolonjskega prvo-stopenjskega študijskega programa fizioterapije Zdravstvene fakultete Univerze v Ljubljani (ZFUL) usvojili kompetence, ki so predstavljene kot cilj študija, na fakulteti in v kliničnem okolju po končanem študiju.

Metoda: Ciljna populacija $v$ raziskavi so bili diplomanti bolonjskega študijskega programa, generacije diplomantov študijskih let od 2012 do 2015. Izvedena je bila presečna deskriptivna raziskava. ZFUL ponuja triletni študij fizioterapije (180 kreditnih točk - KT, po ECTS) in ga sestavljajo teoretični del študija (46\%) in praktično usposabljanje na ZF in v kliničnih ustanovah (54\%). Študenti morajo tekom študija opraviti 20-tedensko klinično prakso in praktično usposabljanje. Za namen raziskave smo sestavili vprašalnik, ki je bil sestavljen na podlagi učnih načrtov o splošnih in predmetnospecifičnih kompetencah iz študijskega programa. Vseboval je dva vsebinska dela. Prvi del je zajemal samo-ocenjevanje kompetenc (12 vprašanj o splošnih kompetencah in 12 vprašanj o predmetno-specifičnih kompetencah). Diplomanti so bili naprošeni, da odgovorijo, koliko so $v$ času študija $v$ akademskem okolju (predavanja, seminarji, seminarske/laboratorijske vaje) in koliko so $v$ kliničnem okolju razvili določene kompetence. Vprašanja so bila zaprtega tipa in so imela možnosti odgovorov oceno od 1-5: 1 - nič, 2 - malo, 3 - srednje, 4 - dobro, 5 - zelo dobro. Drugi del vprašalnika je vseboval demografska vprašanja. Po opravljeni pilotni anketi $(n=10)$, nismo ugotovili nejasnosti pri sestavi vprašalnika, zato smo jo preko elektronske pošte in spletne aplikacije 1KA (www.1ka.si) razposlali 118 diplomantom. Pred izpolnjevanjem vprašalnika, so bili vsi udeleženci obveščeni o namenu raziskave, prostovoljni udeležbi in anonimnosti. Izpolnjen in poslan vprašalnik je pomenil informirano soglasje. Zbirane niso bile nobene informacije, ki bi jih lahko uporabili za identifikacijo posameznikov, zato ni bila potrebna etična odobritev. Anketo je v celoti izpolnilo 53 diplomantov (8 moških in 45 žensk; odzivna stopnja 44,9\%), starih povprečno 22,8 let (razpon od 22 do 29 let), katerih odgovore smo uporabili za analizo podatkov. Za interpretacijo rezultatov je bila uporabljena univariatna analiza z opisno statistiko. Izračunane so bile povprečne 
vrednosti in standardni odkloni (SO). Za analizo razmerja med demografskimi podatki in pridobljenimi kompetencami je bila uporabljena bivariatna korelacijska analiza med obema spremenljivkama. Pearsonov korelacijski koeficient je bil uporabljen za ugotovitev povezav med starostjo pridobljenimi kompetencami $(P=0<0,01)$, Kendalov tau-b test pa za povezavo med kompetencami in spolom $(P=0<0,01)$. Rezultati so bili analizirani s pomočjo programske opreme SPSS Statistics 22 (IBM Corporation, ZDA).

Rezultati: Diplomanti so ocenili, da je bila vrednost usvojenih vseh kompetenc, splošnih in predmetno-specifičnih, $v$ povprečju 3,58 (SO =0,67). Povprečna ocena vseh kompetenc, pridobljenih na fakulteti je bila $3,41(\mathrm{SO}=0,74)$ in v kliničnem okolju 3,74 $(S O=0,68)$. Najvišja povprečna ocena splošnih kompetenc, pridobljenih na fakulteti je bila $4,21(\mathrm{SO}=1,02)$ in v kliničnem okolju 4,53 (SO = 0,80). Najnižja povprečna ocena je bila na fakulteti $3,51(\mathrm{SO}=1,01)$ in v kliničnem okolju 3,06 (SO = 1,2). Najvišja povprečna ocena predmetno-specifičnih kompetenc, pridobljenih na fakulteti je bila3,60 (SO = $0,98)$ in v kliničnem okolju $4,11(\mathrm{SO}=0,93)$. Najnižja povprečna ocena, pridobljena na fakulteti je bila 3,26 (SO = 1,02) in v kliničnem okolju in 3,11 (SO =1,07). Korelacije med demografskimi značilnostmi študentov in pridobljenimi kompetencami niso bile ugotovljene.

Organizacija: Naše ugotovitve so pokazale, da so študentje razkrili nekatere kritične vidike, ki jih je treba upoštevati pri razvoju njihovih kompetenc med študijem. Kompetence študijskega programa so usvojili bolje v kliničnem okolju kot na fakulteti. Tak rezultat je bil pričakovan, ker študentje dobijo natančnejšo sliko o zapletenosti delovnega mesta $v$ kliničnem okolju in tako lažje primerjajo lastno dojemanje kompetenc z zahtevami delovnega mesta.

Družba: Da bi dobili natančnejšo sliko razvojnega procesa kompetenc študentov med študijem, bi bile potrebne longitudinalne raziskave, kot so vrednotenje kompetenc po določnem času na opravljanju trgu dela. Ker je razvoj kompetenc glavni cilj izobraževanja, je pomembno, da vse zainteresirane strani izrecno razumejo, kaj je kompetenca. Potrebna je analiza, kako učitelji, študenti in sestavljavci učnih načrtov konceptualizirajo kompetence, ki jih zahteva njihovo strokovno področje. Specifične kompetence so cilj posameznih predmetov, splošne pa se pridobivajo pri več različnih predmetih. Ne glede na to morajo biti (ene in druge) transferabilne, prenosljive in uporabne v različnih situacijah, in ne zgolj v kontekstu, kjer so bile pridobljene.

Originalnost: Po našem vedenju do sedaj še nobena študija ni raziskovala samo-oceno kompetenc pri diplomantih fizioterapije v Sloveniji.

Omejitve/nadaljnje raziskovanje: Glavna omejitev naše raziskave je majhen vzorec, zato naših rezultatov ni mogoče posploševati in dejstvo, da je bila raziskava izvedena samo v eni disciplini. Menimo, da so lahko ugotovitve o lastnem dojemanju študentov 
fizioterapije o kompetencah po zaključku študija, pomembne tudi za druga izobraževalna poklicna področja v visokem šolstvu.

Ključne besede: študijski dosežki, visoko šolstvo, kompetence, samo-ocena, strokovno znanje, spretnosti, študenti.

Sonja Hlebš je zaključila štadij na Zdravstveni fakulteti v Ljubljani in na Fakulteti za organizacijske vede Kranj ter magistrirala na University of East London, Department of Rehabilitation Sciences, Združeno kraljestvo. Je višja predavateljica za habilitacijsko področje Fizioterapija. Zaposlena je na Zdravstveni fakulteti v Ljubljani. Je avtorica in soavtorica znanstvenih ter strokovnih člankov objavljenih v domačih in tujih revijah. Njeni raziskovalni interesi zajemajo proučevanje paradigem fizioterapevtske prakse, proučevanje normalnega delovanja gibalnega sistema za prepoznavanje funkcijskih izpadov zaradi začasno ali trajno okvarjenih struktur in proučevanje učinkov različnih fizioterapevtskih pristopov za zdravljenje okvar na gibalnem sistemu.

\section{Self-assessment of Acquired Competencies After Completing Higher Education}

Research Question (RQ): What is the self-assessment of acquired competences of students after completion of higher education?

Purpose: The aim of our study was to determine the extent to which the students of the Bologna first cycle program of physiotherapy at the Faculty of Health Sciences of the University of Ljubljana (FHSUL) acquired the competences presented as the goal of the study program at the faculty and in the clinical setting.

Method: The target population of the study was the generations of graduates from the academic years 2012 to 2015. A descriptive cross-sectional study was conducted. ZFUL offers a three-year degree program in physiotherapy (180 ECTS) and consists of a theoretical part of the study (46\%) and practical training at FHSUL and clinical institutions (54\%). Students are required to complete 20 weeks of clinical practice and practical training during their studies. A questionnaire was developed for the purpose of study based on the curricula on general and subject-specific competencies. It consisted of two parts. The first part included selfassessment of competencies (12 questions on general competencies and 12 questions on subject-specific competencies). Graduates were asked to answer to what extent they had developed competencies in the academic environment (lectures, seminars, seminar/laboratory work) and to what extent they had developed competencies in the clinical environment. The questions were closed type and had the possibility to give answers from 15: 1 - not at all, 2 - low, 3 - medium, 4 - good, 5 - very good. The second part of the 
questionnaire contained demographic data. After conducting a pilot survey ( $n=10)$, we found no ambiguities in the content of the questionnaire, so we emailed it to 118 graduates (www.1ka.si application). Prior to completing the questionnaire, all participants were informed of the purpose of the survey, voluntary participation, and anonymity. The completed and sent questionnaire signified informed consent. No information was collected that could be used to identify individuals, so no ethical approval was required. The survey was completed by 53 graduates ( 8 men and 45 women; response rate $44.9 \%$ ), aged an average of 22.8 years (range 22 to 29 years), whose answers were used for data analysis. Univariate analysis with descriptive statistics was used to interpret the results. Means and standard deviations (SD) were calculated. Bivariate correlation analysis between the two variables was used to analyse the relationship between demographic data and acquired competencies. The Pearson correlation coefficient was used to determine the relationships between age and acquired competencies $(P=0<0.01)$, and the Kendall tau-b test was used to determine the relationship between competencies and gender $(P=0<0.01)$. The results were analysed using SPSS Statistics 22 software (IBM Corporation, USA).

Results: The respondents' self-assessed value of all competencies, general and subjectspecific, was $3.58(S D=0.67)$. The mean value of all competencies acquired in the faculty was $3.41(S D=0.74)$ and in the clinical setting $3.74(S D=0.68)$. The highest mean score of general competencies acquired in the faculty was $4.21(S D=1.02)$ and in the clinical setting was 4.53 $(S D=0.80)$. The lowest mean score was 3.51 in the faculty $(S D=1.01)$ and 3.06 in the clinical setting ( $S D=1.2)$. The highest mean score of subject-specific competencies acquired in the faculty was $3.60(S D=0.98)$ and 4.11 in the clinical setting $(S D=0.93)$. The lowest mean score was $3.26(S D=1.02)$ in the faculty and $3.11(S D=1.07)$ in the clinical setting. No correlations were found between student demographic characteristics and competencies acquired.

Organization: Our results showed that students revealed some critical aspects that need to be considered in the development of their competencies during their studies. The competencies were better mastered in the clinical setting than in the faculty. Such a result was to be expected because students in the clinical setting get a more accurate picture of the complexity of the workplace and are thus better able to compare their own conceptions of competencies with the requirements of the workplace.

Society: To get a more accurate picture of the development process of students' competences during their studies, longitudinal studies would be necessary, such as the assessment of competences after a certain period on the labour market. Since the development of competences is the main goal of education, it is important that all stakeholders explicitly understand what competence is. It is necessary to analyse how teachers, students and curriculum designers conceptualize the competences required for their subject area. Specific competencies are the goal of individual subjects, while general competencies are acquired in 
several different subjects. Nevertheless, they must be (both) transferable and usable in different situations, and not only in the context in which they were acquired.

Originality: To the best of our knowledge, no study has investigated self-assessment of competencies among graduates of physiotherapy in Slovenia.

Limitations / further research: The main limitation of our research is the small sample, so our results cannot be generalized, and the fact that the research was conducted in only one discipline. We believe that the findings on physiotherapy students' self-perceptions of their competencies after graduation may be important for other professions in higher education.

Keywords: academic achievement, higher education, competencies, self-assessment, expertise, skills, students.

Sonja Hlebš, MSc, BSc is a graduate of the Faculty Health Sciences University of Ljubljana and Organizational Sciences Faculty in Kranj and has a master's degree from University East London, Department Rehabilitation Sciences, United Kingdom. She is a senior lecturer in physiotherapy at the Faculty of Health Sciences in Ljubljana. She is the author or co-author of scientific and professional articles published in domestic and foreign journals. Her research areas include the study of different paradigms of physiotherapy practice, the study of normal musculoskeletal function to identify functional limitations due to temporarily or permanently impaired structures, and the study of the effects of different manual approaches of physiotherapy for the treatment of movement disorders. 


\title{
Načela menedžmenta sistemov kakovosti kot gradniki uspešnosti gospodarskih družb
}

\author{
Stojan Črv \\ Fakulteta za organizacijske študije v Novem mestu \\ stojan.crv@fos-unm.si

\section{Mirko Markič} \\ Univerza na Primorskem, Fakulteta za management, Koper \\ mirko.markic@fm-kp.si
}

Raziskovalno vprašanje (RV): Ali načela menedžmenta sistemov kakovosti prispevajo $k$ poslovni uspešnosti gospodarskih družb?

Namen: Namen raziskave je bil opraviti sistematičen pregled domače in tuje strokovne literature avtorjev, ki so obravnavali menedžment sistemov kakovosti in njegov vpliv na poslovno uspešnost gospodarskih družb iz vidika donosa na kapital.

Metoda: S kvantitativnim znanstvenoraziskovalnim pristopom smo opravili sistematičen pregled domače in tuje strokovne literature po javno dostopnih bazah podatkov PQDT Open, ScienceDirect, ProQuest, Mendeley in Google Scholar. Doktorske disertacije v slovenskem jeziku smo iskali tudi v repozitorijih Univerze na Primorskem, Univerze v Novi Gorici, Univerze v Ljubljani, Univerze v Mariboru ter Fakultete za organizacijske študije v Novem mestu. Z uporabo iskalnih pojmov "ISO 9001" in "uspešnost" ter veznika "in" v slovenskem jeziku in "ISO 9001" in "performance" ter veznika "and" v angleškem jeziku smo v raziskavo vključili 19. znanstvenih člankov iz obdobja od leta 2002 do leta 2020 in šest doktorskih disertacij iz obdobja od leta 2011 do leta 2019. Uporabili smo metodo deskripcije in kompilacije rezultatov obravnavanih kvalitativnih in kvantitativnih raziskav.

Rezultati: Ugotovili smo, da učinkovita implementacija menedžmenta sistemov kakovosti prispeva k poslovni uspešnosti gospodarskih družb. Avtorji raziskav so navedli ključna načela menedžmenta sistemov kakovosti in dejavnike poslovne uspešnosti, med katerimi prevladujejo finančni kazalniki. $V$ nobeni od dosedanjih raziskav avtorji niso celovito preučevali vseh sedem načel menedžmenta sistemov kakovosti, na katerih temelji standard ISO 9001:2015. Vpliv implementacije menedžmenta sistemov kakovosti na poslovno uspešnost je bil, s pomočjo kazalnika donosnosti na kapital, obravnavan zgolj v eni raziskavi. Najmanj raziskav je bilo opravljenih $v$ velikih gospodarskih družbah, medtem ko jih $v$ srednje velikih in 
velikih skupaj ni bilo. Na podlagi predhodnih ugotovitev smo identificirali raziskovalno vrzel ter podali predloge za nadaljnje raziskovanje.

Organizacija: S predstavitvijo stanja na področju dosedanjih raziskav smo gospodarskim družbam predstavili najpogosteje obravnavana načela menedžmenta sistemov kakovosti in načine merjenja vpliva na poslovno uspešnost.

Družba: Poslovna uspešnost gospodarskih družb je prepoznana tudi v družbenem okolju, ker si s tem dvigujejo svoj ugled ter prispevajo k trajnostnemu razvoju.

Originalnost: Zaznali smo pomanjkanje raziskav menedžmenta sistemov kakovosti po sedmih načelih standarda ISO 9001:2015. Izpostavljamo tudi vrzel v izrazito skromnem raziskovanju vpliva načel menedžmenta sistemov kakovosti na donosnost kapitala.

Omejitve/nadaljnje raziskovanje: Omejili smo se na 25. raziskav, ki so bile opravljene v obdobju od leta 2002 do leta 2020 ter podali predloge za nadaljnje raziskovanje.

Ključne besede: dejavniki uspeha, gospodarske družbe, kakovost, menedžment, načela, poslovna uspešnost.

Stojan Črv je doktorand študijskega programa Menedžment kakovosti na Fakulteti za organizacijske študije v Novem mestu. Po izobrazbi je magister poslovnih ved in diplomirani inženir strojništva. Zaključil je tudi usposabljanje za Šest Sigma črni pas. Na področju kakovosti deluje že preko 20 let in je vodja kakovosti $v$ industrijskem podjetju ITW Appliance Components d.o.o., ki je del ameriške multinacionalke ITW. Je tudi zunanji oziroma vodilni presojevalec sistema vodenja kakovosti po mednarodnem standardu ISO 9001, sistema ravnanja z okoljem po ISO 14001 ter sistema varnosti in zdravja pri delu po ISO 45001.

Mirko Markič je doktoriral na Univerzi v Mariboru, Fakulteti za organizacijske vede s področja organizacijskih znanosti. Po dvanajstih letih delovanja v gospodarstvu se je zaposlil na takratni Visoki šoli za management Koper, danes Fakulteti za management Koper Univerze na Primorskem, kjer je bil dva mandata prodekan za študijske zadeve in zadolžen za usklajevanje raziskovalno-razvojne dejavnosti. Občasno je sodeloval pri izvedbi študijskih programov na Univerzi v Ljubljani, Univerzi v Mariboru, Univerzi v Novi Gorici in Fakulteti za organizacijske študijev Novem mestu. V tujini je deloval na Univerzi v Nišu, (Republika Srbija), Yasar University, (Turčija) ter Slovenskem izobraževalnem konzorciju (Italija). Je redni profesor za področje managementa in znanstveni svetnik. Vodja / član $\checkmark$ več raziskovalnih in podjetniških projektih. Njegova področja raziskovanja so upravne in organizacijske vede management ter javno zdravstvo (varstvo pri delu).

\section{Quality Management Systems Principles as Elements of Company Performance}

Research Question (RQ): Do the principles of quality management systems contribute to the business performance of companies? 
Purpose: The purpose of the research was to conduct a systematic review of domestic and foreign professional literature of authors who discussed the quality management systems and its impact on the business performance of companies in terms of return on equity.

Method: We performed a systematic review of domestic and foreign professional literature with a quantitative scientific research approach in the public available databases PQDT Open, ScienceDirect, ProQuest, Mendeley and Google Scholar. We searched for doctoral dissertations in the Slovene language in the repositories of the University of Primorska, the University of Nova Gorica, the University of Ljubljana, the University of Maribor and the Faculty of Organizational Studies in Novo mesto. Using the search terms "ISO 9001" and "uspešnost" and the conjunction "in" in Slovene and "ISO 9001" and "performance" and the conjunction "and" in English, we included in the research 19 scientific articles from the period from 2002 until 2020 and six doctoral dissertations from the period from 2011 to 2019. We used the method of description and compiling the results of the considered qualitative and quantitative research.

Results: We found out that effective implementation of quality management systems contributes to the business performance of companies. The authors of the research listed the key principles of quality management systems and business performance factors, among which financial indicators predominate. In none of the previous studies, the authors have comprehensively studied all seven principles of quality management systems, on which the ISO 9001:2015 standard is based. The impact of the implementation of quality management systems on business performance, evaluated by the return on equity indicator, was discussed in only one study. The least research was conducted in large companies, while they were not performed in medium-sized and large companies together. Based on the previous findings, we identified a research gap and made suggestions for further research.

Organization: By presenting the situation in the field of previous research, we presented to companies the most frequently discussed principles of quality management systems and methods of measuring the impact on business performance.

Society: The business success of companies is also recognized in the social environment and they raise their reputation and contribute to sustainable development based on this.

Originality: We perceived a lack of research of seven principles of the quality management systems according to the ISO 9001:2015 standard. We are also exposing the gap in the extremely modest research on the impact of the principles of quality management system on return on equity.

Limitations / further research: We limited our research on the 25 surveys conducted in the period from 2002 to 2020 and made suggestions for further research.

Keywords: success factors, companies, quality, management, principles, business performance. 
Stojan Črv is a doctoral student of Quality Management at the Faculty of Organization Studies in Novo mesto. He has a Master's Degree in Business Sciences and a BSc in Mechanical Engineering. He has also completed the Six Sigma Black Belt training. Mr Črv has been working in the field of quality for more than 20 years and is the quality manager at industrial enterprise ITW Appliance Components d.o.o., which is a part of the American multinational corporation ITW. He is also an external or leading auditor of the quality management system according to ISO 9001 standard, of the environmental management system according to ISO 14001 standard as well as of the occupational health and safety management system according to ISO 45001 standard.

Mirko Markič received a doctoral degree from the Faculty of Organisational Sciences, the University of Maribor. After working in the economic sector for 12 years, he started employment with the College of Management, Koper - today's Faculty of Management, the University of Primorska. He was the Associate Dean for Undergraduate Education and in charge of coordinating research and development activities for two terms of office. He was also involved in teaching at the University of Ljubljana, the University of Maribor, the University of Nova Gorica and the Faculty of Organization Studies in Novo mesto. He cooperated with foreign institutions: the University of Niš (Serbia), Yasar University (Turkey) and the Slovene Education Consortium (Italy). Mirko Markič is a professor of management and a research councillor. He is also a head/member of many research and entrepreneurial projects. His fields of research are administration and organization sciences - management in general and management in the field of public health service (health and safety at work). 


\title{
Komunikacijske kompetence $v$ terciarnem e-izobraževanju
}

\author{
Monja Pust \\ Fakulteta za organizacijske študije $v$ Novem mestu \\ monja.pust@fos-unm.si
}

Annmarie Gorenc Zoran

Fakulteta za organizacijske študije $v$ Novem mestu a.zoran@fos-unm.si

Raziskovalno vprašanje (RV): Kateri gradniki komunikacijskih kompetenc so prepoznani kot doprinos e-izobraževanja in kateri predstavljajo izziv pri tovrstnem izobraževanju na višjih strokovnih šolah, ki predstavljajo del terciarnega izobraževanja? Kateri prepoznani gradniki komunikacijskih kompetenc tako oblikujejo nov model komunikacijskih kompetenc v korelaciji z e-izobraževanjem?

Namen: Namen raziskave je osvetliti in prepoznati gradnike komunikacijskih kompetenc pri eizobraževanju višjih strokovnih šol in oblikovati nov model komunikacijskih kompetenc $v$ korelaciji z e-izobraževanjem.

Metoda: $V$ raziskavi bi uporabili več metod, in sicer metodo zbiranja in preučevanja literature, metodo komparacije, metodo treh fokusnih skupin in strukturiranega ali polstrukturiranega intervjuja. Izvedli bi empirično kvalitativno analizo dobljenih rezultatov, analizirali bi pojme 3. reda pri intervjujih, analizirali fokusne skupine, uporabili tehniko ključnih besed v kontekstu in analizo diskurza. $V$ raziskavo bi bili vključeni višješolski učitelji treh največjih šol v Sloveniji.

Rezultati: Predstavljeni so modeli komunikacijskih kompetenc in e-izobraževanja. Upoštevajoč ostale gradnike komunikacijskih kompetenc, prepoznane $v$ literaturi, in empirično prepoznane $v$ samem pedagoškem procesu, se izoblikuje nov model komunikacijskih kompetenc $v$ e-izobraževanju na osnovi široke vključenosti deležnikov pedagoškega procesa v samo e-izobraževanje.

Organizacija: Rezultati raziskave bodo šolam omogočili prepoznati elemente komunikacijskih kompetenc $v$ novem modelu in ga uporabiti v terciarnem okolju za izboljšanje komunikacijskih kompetenc z namenom dvigniti kakovost izobraževalnega procesa v slovenskem prostoru.

Družba: Prepoznavanje novih elementov komunikacijskih kompetenc in oblikovanje novega modela so osnova za dvig kakovosti izobraževalnega procesa in terciarnega šolstva na Slovenskem, kar posledično pripomore $k$ doprinosu znanja $v$ družbi ter ozaveščanju pomena komunikacije pri posredovanju znanja. 
Originalnost: Več raziskav o e-izobraževanju in komunikacijskih kompetencah je bilo že narejenih, nobene pa nismo zasledili, ki bi obravnavala oz. prepoznavala gradnike komunikacijskih kompetenc $v$ okviru e-izobraževanja na terciarnem nivoju v okoliščinah, ko so bili zaradi zdravstvenih izzivov podvrženi e-izobraževanju vsi deležniki pedagoškega procesa.

Omejitve/nadaljnje raziskovanje: Omejili smo se na že narejene raziskave s tega področja. Raziskavo smo izvedli z učitelji terciarnega nivoja treh največjih višjih strokovnih šol v Sloveniji. Model komunikacijskih kompetenc je možno nadalje preveriti na univerzah z namenom prepoznavati pozitivne gradnike komunikacijskih kompetenc in izzive. Prav tako odstira še neraziskano področje vzpostavljanja odnosov med študenti in učitelji pri e-izobraževanju ter prepoznavanju elementov šolanja in e-šolanja, ki so za študente boljši in jih bolj usmerjajo in motivirajo za učenje. Posledično bi lahko ugotovili, v kolikšni meri tradicionalno šolanje ohranja svojo prednost pred e-šolanjem. Na podlagi raziskave je možno nadaljnje raziskovanje tudi v prepoznavanju strategij za odpravo težav e-šolanja na višjih strokovnih šolah, ki so nastale na področju (ne)obvladovanja komunikacijskih kompetenc.

Ključne besede: komunikacijske kompetence, e-izobraževanje, fokusne skupine, polstrukturirani intervjuji, terciarno izobraževanje, model komunikacijskih kompetenc.

Monja Pust je leta 2001 pridobila znanstven naziv magistrica znanosti slovenske književnosti. Zaposlena je kot profesorica in predavateljica na višji strokovni šoli. Trenutno na Fakulteti za organizacijske študije v Novem mestu opravlja doktorat menedžmenta kakovosti.

Annmarie Gorenc Zoran je redna profesorica na Fakulteti za organizacijske študije v Novem mestu in vodi tečaje učenja na daljavo v Sloveniji in tujini. Njeno raziskovalno zanimanje je interdisciplinarni pristop h komunikaciji kot kanal e-izobraževanja, okvir za nenehno izboljševanje v smislu povratnih informacij o standardih kakovosti, orodje v izobraževanju in poučevanju, analitični okvir za raziskave in prispevek k organizacijski znanosti. Je urednica revije Izzivi prihodnosti in aktivna recenzentka mednarodnih indeksiranih revij. Aktivna je tudi pri evalvaciji kakovosti v visokošolskem izobraževanju. Objavila je poglavja o knjigah, številne članke in jih predstavila na mednarodnih, državnih in regionalnih konferencah. 


\section{Communication Competencies in Tertiary e- Learning}

Research Question (RQ): Which building blocks of communication competencies are recognized as a contribution to e-learning and which pose a challenge in higher education vocational schools? Which elements of communication competencies thus form a new model of communication competencies in e-learning?

Purpose: The purpose of the research is to shed light on and identify the building blocks of communication competencies in e-learning in higher education vocational schools (short first cycle programmes) and to form a new model of communication competencies in e-learning.

Method: Several methods would be used in the research, namely the method of collecting and reviewing the literature, the comparison method, the method of three focus groups and the use of structured or semi-structured interview. We would perform an empirical qualitative analysis of the results obtained, analyse third order concepts in interviews, analyse focus group data, use the keywords in context approach and discourse analysis. The research would include higher education teachers from the three largest higher education vocational schools in Slovenia.

Results: Elements of communication competencies and e-learning will be presented. Considering other elements of communication competencies identified in the literature and empirically recognized, a new model of communication competencies in e-learning will be formed based on the broad involvement of stakeholders in the pedagogical/andragogical process in e-learning itself.

Organization: The results of the research will enable schools to identify elements of communication competencies in the proposed new framework and use it in tertiary vocational environments to improve communication competencies and raise the quality of the educational process in Slovenia.

Society: Recognition of new elements of communication competencies and creation of a proposed framework are the basis for raising the quality of the educational process and tertiary vocational education in Slovenia, which consequently contributes to knowledge in society and raising awareness of the importance of communication in knowledge transfer.

Originality: Several studies on e-learning and communication competencies have already been done, but we have not found any that would address or. identify the elements of communication competencies in the context of e-learning at the tertiary vocational level in circumstances where, due to global pandemic challenges, all stakeholders in the pedagogical process were subjected to e-learning.

Limitations / further research: We limited ourselves to the research already completed in this area. The research was conducted with tertiary vocational level teachers in three largest 
vocational higher education institutions in Slovenia. The proposed framework of communication competencies elements in e-learning can be further tested at other tertiary levels to identify the elements of communication competencies and challenges in e-learning. It also reveals the unexplored field of establishing relationships between students and teachers in e-learning and identifying elements of schooling and e-learning that are better for students that facilitate and motivate them to learn more. As a result, we could determine the extent to which traditional schooling maintains its advantage over e-learning. Further research is also possible in identifying strategies for providing possible alternative to challenges in higher vocational schools utilizing e-learning that stem from (non) management of communication competencies.

Keywords: communication competences, e-learning, focus groups, semi-structured interviews, tertiary education, communication competence model.

Monja Pust in 2001 obtained the scientific title of Master of Science of Slovenian Literature. She is employed as a professor and lecturer at a vocational college. She is currently pursuing a doctorate in quality management at the Faculty of Organizational Studies in Novo mesto.

Annmarie Gorenc Zoran is a Professor at the Faculty of Organisation Studies in Novo mesto as well as teaches distance learning courses in Slovenia and abroad. Her research interest is an interdisciplinary approach to communication, as a channel in e-learning, framework for continuous improvement in terms of quality standards feedback, a tool in education and teaching, as an analytical framework to research, and as a contribution to management. She is the editor of the journal Challenges of the Future and is an active peer reviewer for international indexed journals. She is also active in evaluating quality in higher education. She has published book chapters, numerous articles, and presented at international, national, and regional conferences. 


\section{Modeli zrelosti menedžmenta projektov in poslovna uspešnost pri prijavi na javne razpise}

\section{Tinkara Primožič}

Fakulteta za organizacijske študije v Novem mestu

tinkara.primozic@fos-unm.si

\section{Mirko Markič}

Univerza na Primorskem, Fakulteta za management, Koper mirko.markic@fm-kp.si

Raziskovalno vprašanje (RV): Kako uporaba izbranih modelov zrelosti menedžmenta projektov vpliva na poslovno uspešnost pri prijavi na javne razpise?

Namen: Namen raziskave je bil opraviti analizo in sintezo domače in tuje strokovne literature o različnih modelih zrelosti menedžmenta projektov in načinov metodološkega določanja stopnje zrelosti ter njihovega vpliv na poslovno uspešnost pri prijavi na javne razpise.

Metoda: Opravili smo sistematični pregled strokovne literature, domače in tuje. S kvantitativnim znanstvenim pristopom smo raziskovali po javno dostopnih bazah podatkov Web of Science. Doktorske disertacije v slovenskem jeziku smo iskali v sistemu znanstvenih in strokovnih objav Univerze v Ljubljani, Univerze na Primorskem, Univerze v Novi Gorici in Fakultete za organizacijske študije $v$ Novem mestu. Iskali smo z uporabo ključev »menedžment projektov« in »uspešnost « ter »modeli zrelosti« in »management projektov« z veznikom »in«, angleško "project management" in "project success" ter "maturity model« in "project management « z veznikom »and«. Uporabili smo metodo deskripcije in kompilacije rezultatov obravnavanih kvalitativnih in kvantitativnih raziskav.

Rezultati: Ugotovili smo, da je metoda določanja stopnje zrelosti menedžmenta projektov novejša aktivnost. Prva določanja stopnje zrelosti menedžmenta projektov so se pojavile leta 1990 in sicer najprej za potrebe informacijskih podjetij in industrije. Avtorji poudarjajo, da naj bi zaradi potreb po hitrih prilagoditvah znotraj menedžmenta projektov, določanje stopnje zrelosti postalo vrlina $v$ vsaki sodobni organizaciji. Avtorji za uspešnost projektov $v$ večini naslavljajo "železni trikotnik» čas, strošek, kakovost in zadovoljstvo investitorjev. Na uspešnost projektov po novejših raziskavah vpliva tudi podpora menedžerjev, kar nas vodi $k$ pomenu zrelosti znotraj projektnega tima. 
Organizacija: Raziskava pripomore k hitrejši izbiri ustreznega modela zrelosti, ta pa vpliva na boljšo organizacijo postopkov znotraj menedžmenta projektov. Boljša organiziranost pomeni hitrejši odziv, manjše stroške ter manj stresa boljše delovne pogoje znotraj projektne pisarne. Družba: Raziskava ima širok vpliv na družbo, kajti s takim pristopom v organizaciji določijo smernice izboljšav na področju menedžmenta projektov. Projektno izvajanje omogoča hitrejše odzivanje na konkurenčnost tržišča. Izboljšave neposredno pozitivno vplivajo na naravno okolje za katerega organizacija deluje. Boljša organiziranost pomeni hitrejši razvoj. Hitrejši razvoj pa prinaša boljše družbene razmere prebivalcev, kot so pogoji dela in kakovost življenja. Originalnost: Pri analizi strokovne literature smo zaznali pomankanje raziskav, ki povezujejo pomen modelov zrelosti menedžmenta projektov in poslovno uspešnost organizacij pri prijavah na javne pozive.

Omejitve/nadaljnje raziskovanje: Na uspešnost pri prijavah na javne pozive poleg stopnje zrelosti vplivajo tudi drugi zunanji dejavniki, ki bi jih bilo potrebno raziskati. Pri javnih pozivih pa ugotavljamo tudi manko pri kontroli rezultatov teh javnih pozivov na terenu.

Ključne besede: javni razpisi, literatura, menedžment projektov, modeli zrelosti, poslovanje, uspešnost.

Tinkara Primožič je doktorandka študijskega programa Menedžment kakovosti na Fakulteti za organizacijske študije $\checkmark$ Novem mestu. Po izobrazbi je univerzitetna diplomirana geografinja, smer geografija kontaktnih prostorov. Zaposlena je na Regionalni razvojni agenciji Zeleni kras, d.o.o. Znotraj pisarne LAS (Lokalna akcijska skupina) Notranjska opravlja delo prvostopenjske kontrole prijav na javne razpise in nosi odgovornost črpanja denarnih sredstev na ESRR in EKSRP skladu za zunanje izvajalce projektov. Pri tržnem delu opravlja funkcijo vsebinskega usklajevanje glede na želje prijaviteljev in potrebe okolja, koordinacijo pridobivanja dovoljenj, soglasij s področja gradbene zakonodaje, kulturno-varstvene, okoljevarstvene, delovnopravne in finančne zakonodaje. Preko Splošnih razvojnih nalog sodeluje pri pripravi Regionalnega razvojnega programa.

Prof. Dr. Mirko Markič Mirko Markič je doktoriral na Univerzi v Mariboru, Fakulteti za organizacijske vede s področja organizacijskih znanosti. Po dvanajstih letih delovanja v gospodarstvu se je zaposlil na takratni Visoki šoli za management Koper, danes Fakulteti za management Koper Univerze na Primorskem, kjer je bil dva mandata prodekan za študijske zadeve in zadolžen za usklajevanje raziskovalno-razvojne dejavnosti. Občasno je sodeloval pri izvedbi študijskih programov na Univerzi v Ljubljani, Univerzi v Mariboru, Univerzi v Novi Gorici in Fakulteti za organizacijske študijev Novem mestu. V tujini je deloval na Univerzi v Nišu, (Republika Srbija), Yasar University, (Turčija) ter Slovenskem izobraževalnem konzorciju (Italija). Je redni profesor za področje managementa in znanstveni svetnik. Vodja / član v več raziskovalnih in podjetniških projektih. Njegova področja raziskovanja so upravne in organizacijske vede - management ter javno zdravstvo (varstvo pri delu). 


\section{Project Management Maturity Model and Business Success in Applying for Public Tenders}

Research Question (RQ): How does the use of project management maturity model affect business success when applying for public tenders?

Purpose: The purpose of the research was to analyse and synthesize domestic and foreign professional literature on different models of project management maturity and methods of methodological determination of the level of maturity and their impact on business success in applying for public tenders.

Method: We performed a systematic review of professional literature, domestic and foreign. With a quantitative scientific approach, we researched on publicly available Web of Science databases. We searched for doctoral dissertations in the Slovene language in the system of scientific and professional publications of the University of Ljubljana, the University of Primorska, the University of Nova Gorica and the Faculty of Organizational Studies in Novo mesto. We searched using the keys "project management " and "performance" and "maturity models" and "project management« with the conjunction "and«. We used the method of describing and compiling the results of the considered qualitative and quantitative research.

Results: We found that the method of determining the degree of maturity of project management is a recent activity. The first determinations of the level of maturity of project management appeared in 1990, first for the needs of information companies and industry. The authors emphasize that due to the need for rapid adjustments within project management, determining the degree of maturity should become a virtue in any modern organization. The authors mostly address the "iron triangle" of time, cost, quality and investor satisfaction for the success of projects. According to recent research, the success of projects is also influenced by the support of managers, which leads us to the importance of maturity within the project team.

Organization: The research helps to speed up the selection of the appropriate maturity model, which in turn affects the better organization of procedures within project management. Better organization means faster response, lower costs and less stress, better working conditions within the project office.

Society: The research has a wide impact on society, because with such an approach, the organization sets guidelines for improvements in the field of project management. Project implementation enables faster response to market competitiveness. Improvements have a direct positive impact on the natural environment for which the organization operates. Better organization means faster development. Faster development, however, brings better social conditions for the population, such as working conditions and quality of life. 
Originality: In the analysis of the professional literature, we detected a lack of research that links the importance of models of project management maturity and the business success of organizations in applying for public tender.

Limitations / further research: In addition to the level of maturity, the success of applications for public tenders is also influenced by other external factors that should be investigated. In the case of public tenders, we also note a lack of control over the results of these public tenders in the field.

Keywords: public tenders, literature, project management, maturity models, business, performance.

\begin{abstract}
$* * *$
Tinkara Primožič is a doctoral student in the study program Quality Management at the Faculty of Organizational Studies in Novo mesto. She has a university degree in geography, majoring in geography of contact spaces. She is employed at the Regional Development Agency Green karst, Ltd. Within the office of the LAG (Local Action Group) Notranjska performs the work of first-instance control of applications for public tenders and is responsible for drawing funds from the ERDF and EAFRD fund for external project contractors. In market work, it performs the function of content harmonization according to the wishes of applicants and the needs of the environment, coordination of obtaining permits, consents in the field of construction legislation, cultural protection, environmental protection, labor law and financial legislation. It participates in the preparation of the Regional Development Program through the General Development Tasks.
\end{abstract}

Prof. Mirko Markič received a doctoral degree from the Faculty of Organisational Sciences, the University of Maribor. After working in the economic sector for 12 years, he started employment with the College of Management, Koper - today's Faculty of Management, the University of Primorska. He was the Associate Dean for Undergraduate Education and in charge of coordinating research and development activities for two terms of office. He was also involved in teaching at the University of Ljubljana, the University of Maribor, the University of Nova Gorica and the Faculty of Organization Studies in Novo mesto. He cooperated with foreign institutions: the University of Niš (Serbia), Yasar University (Turkey) and the Slovene Education Consortium (Italy). Mirko Markič is a professor of management and a research councillor. He is also a head/member of many research and entrepreneurial projects. His fields of research are administration and organization sciences - management in general and management in the field of public health service (health and safety at work). 


\section{Objektivni postopek segmentacije dobaviteljev ali blagovnih skupin $v$ Kraljičevo matriko}

\section{Božidar Lenarčič}

Fakulteta za organizacijske študije $v$ Novem mestu bozidar.lenarcic@gmail.com

Raziskovalno vprašanje (RV): Dandanes nabavna funkcija uporablja metode in postopke, ki organizacijam celovito dviga konkurenčno prednost $\mathrm{s}$ strateško usmerjenim delovanjem, ki ima trajnostne učinke. Prvi korak v procesu oblikovanja nabavne strategije je segmentacija dobaviteljev ali blagovnih skupin s pomočjo orodja Kraljičeve matrike. Ob predpostavki, da različne situacije zahtevajo različne aktivnosti ter da je postopek segmentacije dobaviteljev ali blagovne skupine subjektivno naravnan sklepamo, da rezultat posplošene segmentacije vodi k ponavljajočimi se nabavnimi strategijami, ožjemu izboru oblikovanja strategij in pasivnem obnašanju nabavne funkcije. Iz te percepcije razvijamo raziskovalno vprašanje: »Kakšen je učinkovit objektivni postopek segmentacije dobaviteljev ali blagovnih skupin«?

Namen: Osnovni namen je usvojiti razumevanje Kraljičeve matrike in postopek segmentacije. $\checkmark$ nadaljevanju študije želimo pridobiti ključne usmeritve za objektiven postopek segmentacije.

Metoda: $\vee$ prvem delu raziskave bomo pregledali obstoječo literaturo na temo Kraljičeve matrike in $s$ tem usvojili razumevanje segmentacije dobaviteljev ali nabavnih skupin. $\mathrm{V}$ nadaljevanju študije bomo $z$ intervjuvanjem izbrane stroke pridobili strokovno razumevanje in izvajanje Kraljičeve matrike $v$ praksi. $V$ naslednjem sklopu metodologije bomo uporabili kvalitativno analitično orodje tematske mreže na obsegu sklopov pregledane literature in pol strukturiranega intervjuja fokusne skupine treh specialistov.

Rezultati: V sklopu rezultatov sledi prikaz analize pridobljenih podatkov predhodno predstavljenega procesa razvoja in oblikovanja tematskih mrež. Rezultati prikazujejo proces razvoja tematske mreže na obsegu sklopov pregledane literature in pol strukturiranega intervjuja študije objektivnega postopka segmentacije dobaviteljev ali blagovnih skupin.

Organizacija: S učinkovitim delovanjem nabavne funkcije in iskanjem priložnosti za preboj organizacijam doprinese študija pomembno dodano vrednost. Dodatna vrednost je lahko v obliki znižanja nabavnih cen, zmanjšanja skupnih stroškov, zmanjšanja tveganja dobavne verige ali zagotavljanja povečanih inovacij iz nabavnega trga. 
Družba: Celotna družba lahko pridobi na medsebojnem organizacijskem razumevanju, ki pri oblikovanju strategij vključuje pojme kot so trajnost, okolje, družba, kultura in napredek.

Originalnost: Prispevek študije za izvajalca segmentacije deluje kot praktični vodnik za objektivno upravljanje dobaviteljev ali blagovnih skupin.

Omejitve/nadaljnje raziskovanje: Raziskava je omejena na navedene vire $v$ literaturi in intervjuvancev. Nadaljevanje raziskave priporočamo $v$ širšem zajemu obsega literature, zajemu večje in/ali homogene skupine intervjuvancu za namen strukturiranega intervjuja. Priporočamo nadaljevanje študije $v$ smeri izbiranje ustrezne komunikacije za pridobivanje soglasja internih kupcev pri izvajanju strategij.

Ključne besede: strategija, nabavna funkcija, Kraljičeva matrika, segmentacija, dobavitelji, blagovna skupina.

Božidar Lenarčič je diplomiral na Višja strokovna šola v Novem mestu in pridobil naziv Inženir elektronike. Študij je nadaljeval na magistrskem študiju Menedžmenta kakovosti $v$ Novem mestu in izobraževanje usmerjal $v$ raziskovanje nabavnih pogajanj. Je avtor člankov iz naslova pogajanj in ostalih nabavnih tematik. V letu 2018 je pridobil tudi certifikat poslovne šole IEDC Bled za General Management Program with Purchasing Specialization. Paralelno je profesor na Fakulteti za organizacijske študije v Novem mestu.

\section{An Objective Approach of Segmentation of Suppliers or Purchasing Categories into the Kraljic Matrix}

Research Question (RQ): Nowadays, the purchasing functions use methods and procedures that comprehensively raise the competitive advantage of organizations through strategically oriented operations that have sustainable effects. The first step in the process of creating a purchasing strategy is the segmentation of suppliers or purchasing categories by using the Kraljic Matrix. Assuming that different situations call for different activities and that the process of segmentation of suppliers or purchasing categories is subjective, we conclude that the result of generalized segmentation leads to repetitive purchasing strategies, a limited strategy selection and passive purchasing behavior. From this perception we develop a research question: "Which is the effective objective process of segmentation of suppliers or purchasing categories"? 
Purpose: The basic purpose of this study is the understanding of the Kraljic Matrix and the segmentation. Next purpose is to obtain key guidelines for the objective segmentation process.

Method: In the first part of the research, we will review the existing literature on the topic of the Kraljic Matrix and thus acquire an understanding of the segmentation of suppliers or purchasing categories. In the following the study, we will gain professional understanding and implementation of the Kraljic Matrix in practice by interviewing the chosen profession. In the set of methodologies, we will use a qualitative analytical tool of a thematic network on the scope of sets of reviewed literature and a semi-structured interview of a focus group of three specialists.

Results: The results are followed by an analysis of the obtained data from the previously presented process of development and design of thematic networks. The results show the process of developing a thematic network on the scope of sets of reviewed literature and a semi-structured interview study of the objective process of segmentation of suppliers or purchasing categories.

Organization: Through the efficient operation of the purchasing function and the search for breakthrough opportunities, the study brings significant added value to organizations. The added value can be seen in the form of price reductions, reducing total costs, reducing supply chain risk or providing increased innovation from the purchasing market.

Society: The whole society can benefit from mutual organizational understanding, which includes concepts such as sustainability, environment, society, culture and progress by creating strategies.

Originality: The study contribution for the segmentation contractor acts as a practical guide for the objective management of suppliers or purchasing categories.

Limitations/Future Research: The research is limited to the written sources in the literature and the interviewees. We recommend continuing the research in a wider range of the scope of the literature, capturing a larger and / or homogeneous group to the interviewee for the purpose of a structured interview. We recommend continuing the study in the direction of selecting the appropriate communication to obtain the consents of internal customers in the implementation of strategies.

Keywords: strategy, purchasing function, Kraljic Matrix, segmentation, suppliers, purchasing categories. 
Božidar Lenarčič has graduated at the College in Novo mesto and obtained the title of Electronics Engineer. He continued his studies at the Master's degree in Quality Management in Novo mesto and focused his education on researching procurement negotiations. He is the author of articles on negotiations and other procurement topics. In 2018, he also obtained the IEDC Bled Business School certificate for the General Management Program with Purchasing Specialization. He is also a professor at the Faculty of Organizational Studies in Novo mesto. 


\title{
Gradniki modela kakovosti delovnega življenja med slovenskimi zdravniki in vpliv na pripadnost organizaciji
}

\author{
Tea Šikovec \\ Fakulteta za organizacijske študije $v$ Novem mestu \\ tea.sikovec@fos-unm.si
}

Raziskovalno vprašanje (RV): Kateri so gradniki kakovosti delovnega življenja med slovenskimi zdravniki, kakšna je stopnja pripadnosti organizaciji in kakšen je vpliv kakovosti delovnega življenja na pripadnost organizaciji?

Namen: Namen je proučiti dejavnike, ki vplivajo na kakovost delovnega življenja med slovenskimi zdravniki, ugotoviti najmočnejše dejavnike, ki prispevajo k nezadovoljstvu med slovenski zdravniki, ugotoviti najmočnejše stresorje, mehanizme samozaščite in prilagajanja ter ugotoviti vpliv kakovosti delovnega življenja na pripadnost zdravniškemu poklicu in organizaciji v kateri so zdravniki zaposleni.

Metoda: $V$ kvantitativnem delu raziskave bomo pridobili podatke $z$ vprašalnikom, ki ga bomo poslani vsem delovno aktivnim slovenskim zdravnikom. Sestavili bomo vprašalnik, ki bo spraševal o iz teorije opredeljenih glavnih dejavnikih kakovosti delovnega življenja, o mehanizmih samozaščite in prilagajanja. Sestavljen vprašalnik bo slonel na najpogosteje uporabljenih že obstoječih vprašalnikih, ki merijo kakovost delovnega življenja, mehanizme samozaščite in prilagajanja ter občutek pripadnosti. $V$ kvalitativnem delu pa bomo glede na izsledke kvantitativnega dela opravili intervjuje v fokusni skupini.

Rezultati: S pomočjo rezultatov kvantitativne raziskave bomo opredelili in izdelali model gradnikov kakovosti poklicnega življenja in opredelili povezavo do pripadnosti organizaciji. Iz kvalitativnega dela raziskave pa bomo potrdili gradnike modela ter osvetlili in umestili vzroke stanja kakovosti delovnega življenja. Ugotovili bomo povezavo kakovosti delovnega življenja na pripadnost organizaciji.

Organizacija: Iz teorije in prakse je poznano, da je nezadovoljstvo in slaba kakovost delovnega življenja povezana z nižanjem kakovosti storitve ter lahko vodi do izgube usposobljenega kadra z menjavo delodajalcev. Raziskava bo $v$ pomoč vodjam organizacij pri možnih optimizacijah delovnega okolja in kakovosti življenja na delovnem mestu zdravnikov, kar lahko pozitivno vpliva na rekrutiranje in zadržanju usposobljenega zdravniškega kadra.

Družba: Nizka kakovost delovnega življenja zdravnikov ima tudi širši vpliv na družbo. Pri že tako ali tako nizkem številu zdravnikov v Sloveniji lahko vodi v opustitev oz. izstop zdravnikov 
iz zdravniške stroke ali v migracijo zdravnikov v tujino. To ima negativen vpliva na dostopnost in kakovost zdravstvenega sistema in zdravstvene oskrbe. Izsledki raziskave lahko vodijo snovalce zdravstvenega sistema k ukrepom za zmanjševane upada zdravnikov. Kakovost poklicnega življenja med zdravniki je tako lahko eden izmed indikatorjev kakovosti zdravstvenega sistema. Sestavljeni vprašalnik bi se lahko uporabil za oceno uspešnosti morebitne prihodnje zdravstvene reforme.

Originalnost: Model kakovosti delovnega življenja bo predstavljal izvirni prispevek na podlagi preučevanja slovenskih delovno aktivnih zdravnikih. Raziskava o kakovosti poklicnega življenja in vplivu na pripadnost delovni organizaciji bo $v$ našem prostoru prva, ki bo zajemala vse delovno aktivne zdravnike in bo vključevala tako kvantitativno kot kvalitativno metodologijo. Omejitve/nadaljnje raziskovanje: Nadaljnje raziskave bi lahko opredelile povezavo in posledice nizke kakovosti življenja na delovnem mestu z znižano kakovostjo zdravstvene oskrbe ter posledice na obremenitev zdravstvenega sistema.

Ključne besede: zdravniki, kakovost delovnega življenja, zadovoljstvo na delovnem mestu, pripadnost organizaciji, zdravstveni sistem.

Tea Šikovec je po diplomi na Medicinski fakulteti Univerze v Ljubljani opravila specialistični izpit iz radiologije z odliko. Uspešno je opravila tudi evropsko diplomo iz radiologije (EDiR). Prvi dve leti po specialističnem izpitu je službovala v SB Novo mesto kot specialistka radiologije, trenutno pa je zaposlena na Onkološkem inštitutu v Ljubljani ter $v$ Kirurški kliniki Avelana na Otočcu. Ukvarja se z onkološko radiologijo ter z diagnostiko in interventnimi posegi na venskem sistemu.

V študijskem letu 2020/21 je vpisala podiplomski študij na Fakulteti za organizacijske študije v Novem mestu.

$* * *$

\section{Building Blocks of the Quality of Working Life Model and its Impact on Organizational Commitment among Slovenian Medical Physicians}

Research question (RQ): What are the building blocks of quality of working life ( $Q W L$ ), the degree of organizational commitment and what is the correlation between QWL and organizational commitment (OC) among Slovenian physicians?

Purpose: The purpose of the research is to examine factors that affect the quality of working life, to identify the most powerful stressors and coping mechanism, and to determine the impact of quality of working life on organizational commitment among Slovenian physicians. 
Method: In the quantitative part of the research, we will use a questionnaire that will examine the most influential factors of QWL. The questionnaire is going to be based on the most commonly used already existing questionnaires measuring quality of working life, coping mechanisms, and perception of organizational commitment with modification We will highlight the results with interviews in a focus group.

Results: Based on the results of quantitative research, we will identify the building blocks of quality of working life and its connection to organizational commitment. From the qualitative part of the research, we will confirm the building blocks of the model and highlight the possible causes for perceived QWL and OC and determine their correlation.

Organization: Dissatisfaction and poor quality of working life among physicians is associated with a decrease of health system and health care quality. Consequentially it can lead to increased turnover and loosing valuable staff for an organization. The conducted research could be useful for leaders to optimize the working environment and QWL for physicians, which can have a positive impact on the recruitment rate and retention of qualified medical staff.

Society: The low QWL among physicians can have a wider impact on society. It can increase the abandonment of medical profession and rise the migration of doctors abroad. Both has a negative impact on accessibility and quality of the health care and health system. The findings of this research could lead the health system creators to take appropriate action to decrease physicians' migration and mitigate the recruitment. The QWL among doctors is so one of the indicators of the health system quality. In this research designed questionnaire could be used as a tool to assess the effectiveness of a possible future health reform.

Originality: Their still has not been a QWL research executed in Slovenia that would cover all Slovenian practicing physicians and that would examine the building block of QWL and the connection and impact of QWL on organizational commitment.

The originality of this study is in methodological approach using both quantitative and qualitative research.

Limitations/further research: Further research could identify the link and consequences of low QWL with reduced quality of health care and consequent burden on the health system.

Keywords: doctors, quality of working life, job satisfaction, organizational commitment, health system.

Tea Šikovec, after graduating from the Faculty of Medicine of the University of Ljubljana, passed a specialist examination in radiology with distinction. She also successfully completed her European degree in Radiology (EDiR). For the first two years after the specialist examination, she served in SB Novo mesto as a radiology consultant. She is currently employed at the Oncology Institute in Ljubljana and at the Avelana Surgical Clinic in Otočec. She is involved in oncological radiology and diagnostics and interventions on the venous system.

In the academic year 2020/21 she enrolled a doctoral study at the Faculty of Organizational Studies in Novo Mesto. $* * *$ 


\title{
Izzivi obvladovanja sprememb v laboratorijih
}

\author{
Milan Simončič \\ Fakulteta za organizacijske študije v Novem mestu \\ milan.simoncic@fos-unm.si
}

Raziskovalno vprašanje (RV): Preskuševalni in kalibracijski laboratoriji nenehno posodabljajo in nadgrajujejo svojo merilno opremo. S kakšnimi tveganji in izzivi se srečujejo pri tem?

Namen: Ugotavljali smo, kako preskuševalni in kalibracijski laboratoriji v Sloveniji obvladujejo spremembe pri nadgradnji in/ali zamenjavi svoje merilne opreme. Raziskava odgovarja na vprašanja, s katerimi se soočamo pri tehnoloških spremembah merilne opreme in celovitem upravljanju kakovosti v laboratorijski dejavnosti.

Metoda: Kot instrument za pridobivanje potrebnih informacij smo uporabili za ta namen razvit vprašalnik. $K$ sodelovanju smo povabili predstavnike iz 86 kalibracijskih in preskuševalnih laboratorijev, ki v Sloveniji izvajajo akreditirano dejavnost skladno z SIST EN ISO/IEC 17025 in so akreditirani pri Slovenski akreditaciji. Za vrednotenje podatkov, smo poleg opisne in frekvenčne statistike, uporabili nekatere neparametrične statistične teste.

Rezultati: Sodelujoči so v januarju 2021 vrnili 56 v celoti izpolnjenih vprašalnikov. Kot najpogostejši razlog za posodobitev merilne opreme so sodelujoči navedli dotrajanost (44 \%), sledi povečanje kapacitet (23\%). Naložba v novo merilno opremo, v zadnjih treh letih, je v 92 \% upravičila pričakovanja laboratorijev. Prav tako je za skoraj enak delež raziskava potrdila, da so nove instalacije in izbira merilne opreme potekale po pričakovanjih laboratorijev. $83 \%$ novih instalacij in posodobitev $v$ laboratorijih je prispevalo $k$ večji učinkovitosti, nova merilna oprema pa zagotavlja zanesljivejše rezultate merjenj. V $11 \%$ uvedene spremembe, po mnenju uporabnikov, niso bile uspešne. $V$ teh primerih tveganj za nepravilne rezultate niso zmanjšali. Razlogi za to so bili različni. Nekateri so navedli, da nova oprema zahteva znatno dodatno angažiranje osebja zaradi postavitve novih metod, zaradi odprave nepričakovanih zapletov pri instalaciji, zaradi večje zahtevnosti analizatorjev ali zaradi manjše zanesljivosti rezultatov. Upoštevajoč število merilnih sistemov, število oseb, ki obvladuje laboratorijsko opremo in zahtevnost, rezultati niso pokazali statistično značilnih razlik.

Organizacija: Dobljeni podatki so primerljivi z rezultati, ki jih je marca 2020 zbralo ameriško podjetje Lab Manager. Slovenski preskuševalni in kalibracijski laboratoriji se soočajo z enakimi izzivi, tveganji in hotenji, kot primerljivi tuji laboratoriji, to je pomembno sporočilo raziskave. Družba: Raziskava potrjuje, da preskuševalni in kalibracijski laboratoriji uvajajo nenehne spremembe in jih uspešno obvladujejo. To krepi zaupanje v poročane rezultate. Ti vplivajo na 
kakovost in sprejemljivost različnih produktov in storitev $v$ številnih panogah, podpirajo industrijske procese in so $v$ funkciji monitoringa okolja.

Originalnost: Rezultati so neposredno uporabni in relevantni v slovenskem in mednarodnem prostoru. Gre za prvo tovrstno raziskavo v Sloveniji.

Omejitve/nadaljnje raziskovanje: Proučili smo zgolj določene in omejene vidike obvladovanja sprememb v preskuševalnih in kalibracijskih laboratorijih. Nadaljnje raziskave lahko usmerimo $\checkmark$ bolj poglobljeno analizo laboratorijskih sprememb, s poudarkom na različnih ravneh obvladovanja: na osebni, skupinski in organizacijski. Prav tako bi lahko podrobneje analizirali odzivanje laboratorijev $v$ primeru transakcijskih (postopnih, evolucijskih) in transformacijskih (enkratnih, radikalnih) sprememb.

Ključne besede: obvladovanje tveganj, obvladovanje sprememb, laboratorijska dejavnost.

\footnotetext{
$* * *$

Milan Simončič je diplomiral na Fakulteti za kemijo in kemijsko tehnologijo v Mariboru. Z disertacijo »Model vključevanja zunanjih deležnikov v izvajanje družbeno odgovornih načel jedrskih elektrarn«, ki jo je zagovarjal na Fakulteti za organizacijske študije v Novem mestu, je pridobil naziv doktorja znanosti s področja menedžmenta kakovosti. Na Fakulteti za organizacijske študije v Novem mestu je bil izvoljen v naziv docenta.

Kot vodja kemije je zaposlen v Nuklearni elektrarni Krško. Objavil je več člankov, aktivno deluje $v$ strokovnih domačih in mednarodnih organizacijah. Raziskovalno se ukvarja s proučevanjem koncepta družbene odgovornosti, izzivov organizacijske odličnosti, priložnosti energetike v trajnostni družbi, sistemov vodenja kakovosti in kemije vodnih medijev jedrskih elektrarn.
}

\section{Challenges of Managing Changes in Laboratories}

Research Question (RQ): Testing and calibration laboratories are constantly updating and upgrading their measuring equipment. What risks and challenges they face in these processes?

Purpose: We determined how testing and calibration laboratories in Slovenia manage changes in the upgrade and/or replacement of their measuring equipment. The research answers the questions we confront in technological changes of measuring equipment and overall quality management in the laboratory activity.

Method: As a tool for obtaining the necessary information, we used a questionnaire developed for this purpose. We invited representatives from 86 calibration and testing laboratories that perform accredited activity in Slovenia in accordance with SIST EN ISO/IEC 
17025 and are accredited by the Slovenian Accreditation. In addition to descriptive and frequency statistics, we used some nonparametric statistical tests to evaluate the data.

Results: In January 2021, participants returned 56 fully completed questionnaires. As the most common reason for the modernization of measuring equipment, the participants stated wear and tear (44\%), followed by an increase in capacity (23\%). Investment in new measuring equipment, in the last three years, in $92 \%$ met the expectations of laboratories. Also, for almost the same share, the research confirmed that the new installations and the selection of measuring equipment took place according to the expectations of the laboratories. $83 \%$ of new installations and upgrades in laboratories have contributed to greater efficiency, and new measuring equipment provides more reliable measurement results. In $11 \%$ of changes, according to users were not successful. In these cases, the risks of incorrect results are not reduced. The reasons for this were varied. Some stated that the new equipment requires significant additional staff engagement due to the deployment of new methods, due to the elimination of unexpected installation complications, due to the greater complexity of the analysers, or due to the lower reliability of the results. Considering the number of measuring systems, the number of persons managing the laboratory equipment and the complexity of analytical methods, the results did not show statistically significant differences.

Organization: The data obtained are comparable to the results collected in March 2020 by the American company Lab Manager. Slovenian testing and calibration laboratories meet the same challenges, risks and desires as comparable external laboratories, which is an important message of the research.

Society: The research confirms that testing and calibration laboratories introduce continuous changes and successfully manage them. This strengthens confidence in the reported results. These affect the quality and acceptability of various products and services in many industries, support industrial processes and are in the function of monitoring the environment.

Originality: The results are directly useful and relevant in Slovenia and internationally. This is the first research of its kind in Slovenia.

Limitations / further research: We examined only specific and limited aspects of change management in testing and calibration laboratories. Further research can be focused on a more in-depth analysis of laboratory changes, with an emphasis on different levels of management: personal, groups and organizational. Research could also include laboratory responses in the experience of transactional (steady, evolutionary) and transformational (oneoff, radical) changes.

Keywords: risk management, change management, laboratory activity. 
Milan Simončič graduated on the Faculty of Chemistry and Chemical Technology in Maribor. With the dissertation "Model of integrating external stakeholders in the implementation of the principles of social responsibility of nuclear power plants", advocated at the Faculty of Organisation Studies in Novo Mesto, he achieved the title of doctor of science in the field of quality management. He was elected assistant professor at the Faculty of Organizational Studies in Novo mesto. As the head of chemistry department works at the Krško Nuclear Power Plant. He has published several papers, actively works in some professional organizations. His research interests include the concept of social responsibility, the challenges of organizational excellence, the opportunities of energy in a sustainable society, quality management systems and the water chemistry of nuclear power plants. 


\title{
Vloga zunanjega svetovalca pri uvajanju organizacijskih sprememb v procesu proizvajanja
}

\section{Idriz Selimović}

Fakulteta za organizacijske študije v Novem mestu

idrizselimovic@yahoo.com

\author{
Mirko Markič \\ Univerza na Primorskem, Fakulteta za management, Koper \\ mirko.markic@guest.arnes.si
}

Raziskovalno vprašanje (RV): Ali podjetje potrebuje zunanjega svetovalca za izvedbo organizacijskih sprememb.

Namen: Preučiti želimo vlogo zunanjih svetovalcev pri uvajanju organizacijskih sprememb v procesu proizvajanja v organizaciji.

Metoda: V našem članku bomo uporabili: smernice sistematičnega pregleda, smernice integrativnega pregleda študija, smernice meta analize in smernice pregleda literature. Literaturo smo izbirali preko glavnih akademskih bibliografskih baz Web of science, Elsevier, Jstor, Emerald. Za iskanje ustrezne literature smo uporabili ključne besede: Organizational Change, Consultant, Management, Introduction of changes, Process, Consultancy industry.

Rezultati: Medtem ko dodana vrednost, ki jo svetovalci lahko dodajo podjetju, že dolgo privlači pozornost vodstva, je kritično zanimanje za svetovalni postopek relativno novo. Vse večje zanimanje za svetovalce pa je prineslo tudi vedno večjo kritično razpravo o upravičenosti najema svetovalcev. $V$ našem članku bomo predstavili argumente za in proti najemu zunanjih svetovalcev.

Organizacija: Organizacija vedno potrebuje trezen razmislek ali pri uvajanju sprememb potrebuje zunanjega svetovalca.

Družba: Napredek in uspeh se v organizaciji lahko doseže brez dragih zunanjih strokovnjakov in vedno novih pristopov, enostavno z uporabo "zdrave« pameti. S tem pristopom dosežemo da se čim več organizacij bolj posveča implementaciji te zdrave pameti v svoje procese..

Originalnost: $V$ članku izpostavimo ključne elemente katere je potrebno upoštevati pri uvedbi organizacijskih sprememb, da bi se izognili dragim zunanjim svetovalcem

Omejitve/nadaljnje raziskovanje: Podlaga članka so teoretična dognanja svetovnih avtorjev iz preučevanega področja, zanimiva bi bili rezultati empirične raziskave. 
Ključne besede: Organizational Change, Consultant, Management, Introduction of changes, Process, Consultancy industry.

Idriz Selimović se je rodil 17.05.1968 v BiH. Magistriral je na Fakulteti za organizacijske študije v Novem mestu leta 2019. Dela v gospodarstvu in je opravlja različne funkcije od vodje osnovne enote do tehničnega direktorja. Trenutno dela kot pomočnik direktorja proizvodnje, glavna naloga pa je uvajanje načel vitke organizacije v podjetje.

Mirko Markič je doktoriral na Fakulteti za organizacijske vede Univerze v Mariboru s področja organizacijskih ved na temo inoviranja. Po dvanajstih letih delovanja $v$ gospodarstvu se je zaposlil na Fakulteti za management Univerze na Primorskem. Je redni profesor za področje menedžmenta in znanstveni svetnik ter vodja ali član 17 raziskovalnih projektov in projektov z gospodarstvom. Njegova bibliografija obsega več kot 600 enot s področja upravnih in organizacijskih ved ter javnega zdravstva (varstvo pri delu).

\section{The Role of an External Consultant in Introducing Organizational Change}

Research Question (RQ): Does the company need an external consultant to make organizational changes?

Purpose: We want to examine the role of external consultants in introducing organizational change in an organization.

Method: In our article, we will use: systematic review guidelines, integrative study review guidelines, meta-analysis guidelines, and literature review scope guidelines. We selected the literature through the main academic bibliographic databases Web of science, Elsevier, Jstor, Emerald. We used the following keywords to search for relevant literature: Organizational Change, Consultant, Management, Introduction of changes, Process, Consultancy industry. Results: While the added value that consultants can add to a company has long attracted the attention of management, critical interest in the consulting process is relatively new. However, the growing interest in consultants has also brought about a growing critical debate on the justification for hiring consultants. In our article, we will present the pros and cons of hiring external consultants.

Organization: The organization always needs sober thinking or needs an external consultant when introducing changes.

Society: Progress and success in the organization can be achieved without expensive external experts and always new approaches, simply by using "common sense". With this approach, we achieve that as many organizations as possible are dedicated to the implementation of this common sense in their processes. 
Originality: The article highlights the key elements that need to be considered when introducing organizational changes in order to avoid costly external consultants.

Limitations / further research: The basis of the article is the theoretical findings of world authors from the studied field, the results of empirical research would be interesting.

Keywords: organizational change, consultant, management, introduction of changes, process, consultancy industry.

Idriz Selimovic received his master's degree from the Faculty of Organizational Studies in Novo mesto in 2019. He works in the economy, performing various functions from head of basic unit to technical director. He is currently working as an Assistant Production Director, with the primary task of introducing lean organization principles into the company.

Mirko Markič obtained a PhD from the Faculty of Organizational Sciences, University of Maribor in the field of organisation sciences on the topic of innovation. After twelve years of working in economy he got employed at the Faculty of Management, University of Primorska. He is a full professor in the field of management and scientific advisor and a leader or a member of 17 research projects and projects connected to economy. His bibliography includes more than 600 units from the fields of administrative and organisation sciences and public health (safety at work). 


\section{Ključni dejavniki digitalizacije procesov $v$ oskrbni verigi}

\section{Andrej Lukan}

Fakulteta za organizacijske študije v Novem mestu andrej.lukan@gmail.com

Raziskovalno vprašanje (RV): V raziskavi nas zanima kateri so ključni dejavniki sprememb ob digitalizaciji procesov v oskrbni verigi in kako vpliva digitalizacija na organizacije?

Namen: Raziskali bomo, kako digitalizacija vpliva na oskrbno verigo. Cilj je ugotoviti, ključne dejavnike digitalizacije in potrebne spremembe procesov, ki so povezani z njenim uvajanjem v oskrbno verigo.

Metoda: Za namen raziskave smo uporabili kvalitativno metodo. Naredili smo študijo literature ter analizirali pridobljene podatke.

Rezultati: Raziskava je pokazala, da je podjetja in njihove oskrbne verige dajejo velik pomen digitalizaciji. Dodatno je pojav epidemije Koronavirus (SARS-CoV-2) še pospešil širjenje digitalizacije. Delo od doma (izven sedeža podjetja) na področju oskrbovalnih verig je praktično nemogoče izvajati brez ustrezne digitalizacije procesov. Podjetja $v$ procesih materialnega poslovanja uvajajo oblačne rešitve informacijske podpore, ki omogočajo povezovanje navzven. S pomočjo novih tehnologij loT povezujejo procese v enoten sistem. $S$ sodobnimi računalniki, ki omogočajo obdelavo množice podatkov lahko oskrbne verige praktično sproti dobivajo informacije za svoje poslovanje. Evidentirali smo ključne dejavnike in tudi podporo, ki jo s svojim spodbujanjem dajejo tudi države in njihove institucije.

Organizacija: Raziskava omogoča slovenskim podjetjem boljši pregled nad dejavniki digitalizacije in daje napotek kako se strukturirano lotiti teh procesov. Podjetja bodo z raziskavo dobila pregled nad različnimi modeli digitalizacije in njihovo uporabo.

Družba: Podjetja z investiranjem v informatizacijo s področja oskrbovalnih verig ter vlaganjem $\checkmark$ povezovanje in izmenjavo podatkov med partnerji prispevajo $\mathrm{k}$ hitrejšemu in trajnostnemu razvoju. $S$ pomočjo digitalizacije se pospeši in poceni poslovanje ter $s$ povezovanjem in deljenjem podatkov tudi pospeši razvoj.

Originalnost: $\mathrm{V}$ raziskavi smo predstavili ključne dejavnike digitalizacije procesov, ki pripomorejo $k$ lažji in hitrejši gradnji oskrbovalnih verig. Podjetja imajo v veliki meri odpor do spreminjanja procesov in tudi do izmenjave podatkov. O digitalizaciji na splošno je veliko napisanega. Nismo pa zasledili njene obravnave $v$ povezavi s potrebno spremembo procesov še posebej v oskrbni verigi. 
Omejitve/nadaljnje raziskovanje: Raziskovanje je bilo omejeno na zbrano in pregledano literaturo iz področja oskrbovalnih verig v proizvodnih podjetjih. Raziskavo bi bilo smiselno nadaljevati oz. jo razširiti z večjem številom intervjuvancev, vključitvijo tehnike kodiranja in obdelavo pridobljenih podatkov.

Ključne besede: digitalizacija, e poslovanje, informacijski sistem, oblačne rešitve, IoT, procesi, sodelovanje, komunikacija.

Andrej Lukan Na Ekonomski fakulteti v Ljubljani zaključil visokošolsko izobrazba na smeri za denarništvo in finance, specialistični študij na področju Managementa in Magistrski študij na področju Poslovodenje in organizacija. Od leta 1994 zaposlen v Krki, tovarni zdravil, d.d., Novo mesto. Trenutno na delovnem mestu pomočnik direktorja Razvoja in proizvodnje učinkovin z oskrbo, odgovoren za področje logistike. Ima dolgoletne izkušnje na projektih prenove procesov in uvajanja programske podpore na področju materialnega poslovanja, transporta in upravljanja voznega parka.

\section{Key Factors of Digitization Processes in the Supply Chain}

Research Question (RQ): At this research, we are interested in what are the key factors of change during the digitization of processes in the supply chain and how does digitalization affect organizations?

Purpose: We will explore how digitization affects the supply chain. The aim is to identify the key factors of digitization and the necessary changes in the processes associated with its introduction into the supply chain.

Method: We used qualitative method research. We made a study of the literature and analyzed the obtained data.

Results: Research has shown that companies and their supply chains attach great importance to digitalization. Additionally, the outbreak of the Coronavirus epidemic (SARS-CoV-2) has further accelerated the spread of digitization. Working from home (outside the company's headquarters) in the field of supply chains is practically impossible to carry out without proper digitization of processes. In the processes of material management, companies are introducing cloud solutions of information support, which enable external integration. With the help of new loT technologies, they integrate processes into a single system. With modern computers that enable big data analysis, supply chains can receive information for their business practically on the spot. We recorded key factors as well as the support that countries and their institutions also provide through their promotion. 
Organization: The research provides Slovenian companies a better overview of the factors of digitalization and provides guidance on how to tackle these processes in a structured way. The companies will through research get an overview of different models of digitalization and their use.

Society: By investing in informatization in the field of supply chains and investing in the connection and exchange of data between partners, companies contribute to faster and more sustainable development. With the help of digitalization, business is accelerated and economically, and development is also accelerated by connecting and sharing data.

Originality: In the research, we presented the key factors of digitalization processes that contribute to easier and faster construction of supply chains. Businesses have a great deal of resistance to process change and data sharing. Much has been written about digitization in general. However, we did not see its treatment in connection with the necessary process change, especially in the supply chain.

Limitations / further research: The research was limited to the collected and reviewed literature for supply chains in manufacturing companies. It would make sense to continue the research or. expand it with interviewees of supply chain experts, the inclusion of coding techniques, and the processing of acquired data.

Keywords: digitalization, e-business, information system, cloud solutions, loT, processes, cooperation, communication.

\footnotetext{
$* * *$

Andrej Lukan On the Faculty of Economics in Ljubljana, he completed a university degree in monetary and finance, a specialization study in Management, and a Master's degree in Management and Organization. Since 1994 he has been employed by Krka, d.d., Novo mesto. Currently in the position of Assistant Director, R\&D API Production and SCM, responsible for logistics. He has many years of experience in process renovation projects and the introduction of software support in the field of material management, transport, and fleet management.
} 


\title{
Kazalniki kakovosti farmacevtske skrbi ob hipertenziji
}

\author{
Breda Drenek Sotošek \\ LEKOS Lekarna Pod Sv. Rokom, Sevnica \\ bredasotosek@gmail.com
}

Raziskovalno vprašanje (RV): Razvoj kazalnikov kakovosti za kognitivno storitev farmacevtske skrbi ob hipertenziji, ovrednotili jih bodo uporabniki lekarniške storitve v slovenskih lekarnah. Namen: Ocena trenutnega stanja kakovosti izvajanja storitve farmacevtske skrbi ob hipertenziji $v$ slovenskih javnih lekarnah $s$ pomočjo kazalnikov kakovosti na podlagi uporabnikove izkušnje s storitvijo, merjenje le-teh bo omogočalo tako oceno kakovosti v posamezni lekarni kot tudi primerjavo med posameznimi lekarnami ter kronološko primerjavo z namenom uvedbe periodičnih izboljšav pri izvajanju farmacevtske skrbi ob hipertenziji.

Metoda: Za pripravo teoretičnih izhodišč smo uporabili kvalitativne metode raziskovanja z namenom identifikacije glavnih kazalnikov kakovosti storitve farmacevtske skrbi ob hipertenziji v Sloveniji in tujini. Sledila bo empirična raziskava, v ta namen bomo uporabili vprašalnik.

Rezultati: Ustrezna kakovost zdravstvene obravnave je temelj uspešnega zdravljenja, katerega cilj je izboljšanje zdravstvenega stanja. Farmacevt ni le kompetenten strokovnjak za preskrbo z zdravili, ampak predvsem za zdravljenje z zdravili. Pregled uporabe zdravil je storitev optimizacije in racionalizacije uporabe zdravil posameznega bolnika s ciljem izboljšati oziroma vzdrževati bolnikovo z zdravjem povezano kakovost življenja. Farmacevtska intervencija je strokovni poseg nosilca lekarniške dejavnosti v primeru nepopolnosti, nejasnosti ali napak na predpisanem receptu, ki so lahko administrativne ali strokovne narave in bi lahko povzročile ekonomske ali zdravstvene posledice za uporabnika ali zdravstveni sistem ter niso skladne $\mathrm{s}$ temeljnim namenom zdravljenja ali zdravstvenimi pravili. V Sloveniji od 117 bolnikov s povprečno starostjo 66 let $30.2 \%$ njih ne prepoznava potrebe po jemanju zdravil za zniževanje krvnega tlaka, pri $12.9 \%$ bolnikih zaskrbljenost zaradi jemanja zdravil prevlada nad dojemanjem njihovih koristi. Reševanje in preprečevanja z zdravili povezanih težav $v$ okviru storitve farmacevtske skrbi potrjujejo znižanje stroškov za celoten zdravstveni sistem, saj se učinkovitost farmacevtske skrbi kaže na različnih ravneh zdravstvene oskrbe. Naloga stroke je, da oblikuje specifične kazalnike, ki odražajo stopnjo sodelovanja bolnikov pri zdravljenju z zdravili, razumevanje zdravljenja, ustrezne uporabe zdravil in specifične kazalnike farmakoterapije za določena zdravila, populacije in izide zdravljenja. 
Organizacija: Identifikacija kazalnikov kakovosti bo omogočala oceno kakovosti v posamezni lekarni kot tudi primerjavo med posameznimi lekarnami ter kronološko primerjavo z namenom uvedbe periodičnih izboljšav pri izvajanju farmacevtske skrbi ob hipertenziji v lekarnah.

Družba: Identifikacija kazalnikov kakovosti za ovrednotenja povezave med izvajanjem obstoječih smernic farmacevtske skrbi in kakovostjo storitve v smislu varne uporabe zdravil.

Originalnost: Naše temeljno raziskovalno vprašanje je identifikacija kazalnikov kakovosti iz vidika uporabnika storitve. Dosedanje raziskave so se večinoma opirale na kompilanco, adherenco in konkordanco kot kazalnike kakovosti oziroma učinkovitosti storitve farmacevtske skrbi.

Omejitve/nadaljnje raziskovanje: Omejitev raziskave na slovenske javne lekarne.

Ključne besede: farmacevtska skrb, hipertenzija, kazalniki kakovosti, kognitivna storitev.

Breda Drenek Sotošek, rojena 18.10.1947 sem po zaključeni osnovni šoli v Sevnici (1954-62) šolanje nadaljevala na 1.gimnaziji v Celju (1962-66). Po maturi je sledil študij farmacije v Ljubljani, kjer sem diplomirala leta 1974. Leta 1973 sem se zaposlila v JZ Lekarna Sevnica in leta 1976 postala direktorica zavoda (1976-94), v letih 1979-87 sem predsedovala celjski podružnici SFD, leta 1991 pa kot ustanoviteljica posavske podružnice le-tej predsedovala 1991-98. Leta 1987 sem končala kozmetično šolo in odprla kozmetični salon, ki je iz popoldanske obrti prerasel v podjetje LEKOS d.o.o. (1993), 1994 je sledilo odprtje zasebne lekarne. 1991 sem zaključila specializacijo iz farmacevtske informatike, 1997 pa magistrirala iz ekonomskih ved ter leta 2000 opravila šolanje iz homeopatije v avstrijskem Gradcu, 2020 NLP Master. V osemdesetih letih sem poučevala kemijo na STŠ Sevnica, 2010-2012 strokovne predmete programa farmacevtskih tehnikov na ŠC Novo mesto, od 2015-2018 strokovne predmete programa kozmetika na Erudio Ljubljana.

\section{Quality Indicators of Pharmaceutical Care in Hypertension}

Research Question (RQ): Development of quality indicators for the cognitive service of pharmaceutical care in the area of hypertension, evaluated by users of pharmacy service in Slovenian pharmacies.

Purpose: Assessment of the current state of the quality of pharmaceutical care in the case of hypertension in Slovenian pharmacies using quality indicators based on the user's experience with the service. Measuring them will allow both quality assessment in each pharmacy and comparison between individual pharmacies and chronological comparison with a view to 
introducing periodic improvements in the implementation of pharmaceutical care in the case of hypertension.

Method: We used qualitative methods of research in order to identify the main indicators of the quality of the service of pharmaceutical care in the field of hypertension in Slovenia and abroad. Empirical research will follow, and we will use a questionnaire for this purpose.

Results: Adequate quality of medical treatment is the cornerstone of successful treatment, which aims to improve health status. The pharmacist is not only a competent expert in the supply of medicines, but primarily for the treatment of medicines. The review of the use of medicinal products is a service of optimising and rationalising the use of medicinal products by an individual patient with the aim of improving or maintaining the patient's health-related quality of life. Pharmaceutical intervention is a professional intervention by the pharmacy operator in the event of incompleteness, uncertainty or errors in the prescribed prescription, which may be of an administrative or professional nature and could have economic or health consequences for the user or health system and are not consistent with the essential purpose of treatment or health rules. In Slovenia, out of 117 patients with an average age of $6630.2 \%$ do not recognize the need to take blood pressure lowering medicines, in $12.9 \%$ of patients the concern about taking medicines outweighs the perception of their benefits. The resolution and prevention of drug-related problems in the context of the pharmaceutical care service confirms the reduction in costs for the whole health system, as the effectiveness of pharmaceutical care reflects at different levels of health care. The task of the profession is to develop specific indicators that reflect the degree of participation of patients in drug treatment, understanding of treatment, appropriate use of medicinal products and specific indicators of pharmacotherapy for specific medicinal products, populations and outcomes of treatment.

Organization: The identification of quality indicators will allow for quality assessment in each pharmacy, as well as a comparison between individual pharmacies and a chronological comparison with a view to introducing periodic improvements in the implementation of pharmaceutical care in the case of hypertension in pharmacies.

Society: Identification of quality indicators to evaluate the link between the implementation of the existing pharmaceutical care guidelines and the quality of the service in terms of the safe use of medicinal products.

Originality: Our fundamental research question is the identification of quality indicators from the point of view of the service user. The research so far has largely relied on compliance, adherence and concordance as indicators of the quality or effectiveness of the pharmaceutical care service.

Limitations / further research: Limitation of research to Slovenian public pharmacies.

Keywords: pharmaceutical care, hypertension, quality indicators, cognitive service. 
Breda Drenek Sotošek, born 18.10.1947, continued my education at the 1st Grammar School in Celje (1962-66) after completing primary school in Sevnica. After graduating, he studied pharmacy in Ljubljana, where I graduated in 1974. In 1973 I took a job at the JZ Lekarna Sevnica and in 1976 became director of the institute (1976-94), in 1979-87 I chaired the Celje branch of SFD and in 1991 I chaired the Posavje branch in 1991-98. In 1987 I finished cosmetic school and opened a beauty salon, which grew from afternoon crafts to company Lekos d.o.o. (1993), followed in 1994 by the opening of a private pharmacy. In 1991 I completed my specialisation in pharmaceutical informatics, in 1997, received a master's degree in economics and in 2000 completed my education in homeopathy in Graz, 2020 NLP Master. In the 1980s I taught chemistry at STŠ Sevnica, 2010-2012 professional subjects of the program of pharmaceutical technicians at ŠC Novo mesto, from 2015-2018 professional subjects of the cosmetics program at Erudio Ljubljana. 


\title{
Analiza hudih telesnih poškodb $v$ cestnem prometu in vloga urgentnega centra
}

\author{
Nataša Šporčić \\ Univerzitetni klinični center Ljubljana \\ natasasporcic77@gmail.com
}

Franc Brcar

Fakulteta za organizacijske študije $v$ Novem mestu

franc.brcar@gmail.com

Raziskovalno vprašanje (RV): Koliko je bilo hudih telesnih poškodb v prometnih nesrečah in kakšne so te poškodbe v letu 2020?

Namen: Ugotoviti, koliko hudo poškodovanih udeležencev $v$ prometnih nesrečah je bilo leta 2020, kakšen je delež hudih telesnih poškodb po spolu, v katero starostno skupino spada največ hudih telesnih poškodb in kakšen je vpliv vremena na število in resnost hudih telesnih poškodb.

Metoda: Po pregledu relevantne literature smo pridobljene kvantitativne podatke $z$ uradne spletne strani Policije analizirali s frekvenčno statistiko, deskriptivno statistiko in HI-kvadrat testom. Za kvalitativno metodo pa smo uporabili poglobljeni pol-strukturirani intervju z dvema relevantnima strokovnjakoma iz tega področja.

Rezultati: Glede ogroženosti v cestnem prometu obstajajo razlike med moškimi in ženskami, najmlajši in najstarejši so najbolj ogroženi v cestnem prometu in več hudih telesnih poškodb se zgodi ob lepem vremenu.

Organizacija: Vzpostavitev učinkovitega prometno-varnostnega sistema je možna le ob predhodni prepoznavi, analizi in odpravi ključnih vzrokov, ki vplivajo na varnost.

Družba: Večja varnost $v$ cestnem prometu zahteva spremembe v razmišljanju in delovanju posameznika kot udeleženca v prometu.

Originalnost: Originalnost raziskave je v uporabi kombinacije kvantitativne in kvalitativne raziskovalne metode. Tema je iz družbenega stališča zelo zanimiva.

Omejitve/nadaljnje raziskovanje: Rezultati so pod vplivom pandemije COVID-19. Potrebno bi bilo narediti raziskavo za daljše časovno obdobje, vsaj 10 let. 
Ključne besede: prometne nesreče, hude telesne poškodbe, spol, starost, vreme.

Nataša Šporčić je diplomirana medicinska sestra, magistrica zdravstveno-socialnega managementa. Približno 15 let je redno zaposlena na Internistični prvi pomoči, Univerzitetni klinični center Ljubljana. Njena prva zaposlitev je bila v Splošni bolnišnici Celje, Oddelek za splošno in abdominalno kirurgijo. Z Ministrstvom za obrambo, kot pripadnica rezervne sestave slovenske vojske - PPRS Role 2 LM, sodeluje že 10 let. Na Fakulteti za zdravstvene vede Maribor je končala visokošolski študijski program Zdravstvena nega in magistrski študij Management $v$ zdravstvu in socialnem varstvu. Zaključuje tudi Magistrski študij Zdravstvene nege. Na Fakulteti za organizacijske študije Novo mesto je vpisana v 2. letnik doktorskega študijskega programa Menedžment kakovosti.

Franc Brcar je univerzitetni diplomirani inženir strojništva, magister informacijsko-upravljavskih ved in doktor menedžmenta kakovosti. Dalj časa je bil zaposlen v večjem avtomobilskem podjetju. Na začetku je delal kot specialist na področju operacijskih sistemov in baz podatkov. Sledilo je delo na področju uvajanja in vzdrževanja sistemov za računalniško konstruiranje in ERP rešitev. V zadnjem obdobju se raziskovalno ukvarja z menedžmentom, menedžmentom informacijskih tehnologij, menedžmentom poslovnih procesov, inovativnostjo in kakovostjo.

Je predavatelj na več fakultetah na visokošolski, magistrski in doktorski stopnji. Izvaja individualne konzultacije in organizira seminarje za skupine iz statistike (R, SPSS, SAS, Lisrel, ... ), analize kvalitativnih podatkov (ATLAS.ti) in pisanja strokovnih in znanstvenih del (kvalitativne in kvantitativne raziskovalne metode, Word, Excel, PowerPoint, Windows, linux, ... ).

\section{An Analysis of Serious Injuries in Road Traffic and the Role of the Emergency Room}

Research Question (RQ): How many of serious injuries were in traffic accidents, and what were these injures in 2020?

Purpose: To determine how many seriously injured participants in traffic accidents were in 2020 , our purpose was to determine what is the proportion of serious injures by gender, which age group included the most severe injuries and what is the impact of weather on the number and severity of serious injuries.

Method: After reviewing the relevant literature, we used frequency statistic and chi-square tests for the data obtained from the official police website. For the quantitative method, we used an in-depth semi-structured interview with two relevant experts in the field.

Results: Regarding road traffic hazards, there are differences between males and females, the youngest and oldest are most at risk in road traffic, and more severe injuries occur in fine weather.

Organization: The establishment of an effective traffic safety system is possible only with the prior identification, analysis and elimination of critical causes that affect safety. 
Society: Greater road safety requires changes in the individual's thinking and acting as a road user.

Originality: The originality of the research lies in using a combination of quantitative and qualitative research methods. The topic is very interesting from a social point of view.

Limitations / further research: The COVID-19 pandemic effects the results. The research should be done for a more extended period, at least ten years.

Keywords: traffic accident, serious injuries, gender, age, weather.

Nataša Šporčić is a graduate nurse, with a master's degree in health and social management. For about 15 years she has been a full-time employee at the Internistic First Aid, University Clinical Center Ljubljana. Her first job was at the General Hospital Celje, Department of General and Abdominal Surgery. She has been cooperating with the Ministry of Defense as a member of the reserve force in the Slovenian Army - PPRS Role $2 \mathrm{~L}$ for 10 years. She graduated from the Faculty of Health Science in Maribor with a bachelor's degree in Nursing and a master's degree in Management in Health and Social Care. She is also completing her master's degree in Nursing. She is attending the 2. year of PhD Program Quality Management at the Faculty of Organizational Studies Novo mesto.

Franc Brcar is a university graduate in engineering (B.Sc. in Engineering), received his Masters of Science in Informational and Management sciences (M.Sc.) and his PhD in Quality Management. He has had extensive experience working for a major automobile company. He has worked as a specialist in the field of operational systems and databases as well as worked in the introduction and maintenance of systems for computer construction and ERP solutions. Recently he has been examining management, management of IT systems, management of business processes, and management of innovations and quality.

$\mathrm{He}$ is an assistant professor at several faculties at the Bachelor, Masters and PhD level. He is a tutor for research methodology courses, tutor for statistical analysis, conducting workshops on statistical programs (R, SPSS, SAS, Lisrel, ... ), data coding and data analysis (ATLAS.ti), writing scientific and professional research papers and articles (Qualitative and Quantitative Research Methodologies, Word, Excel, PowerPoint, Windows, linux, ... ). 


\title{
Sistematični pregled raziskav na FOŠ
}

\author{
Franc Brcar
}

Fakulteta za organizacijske študije v Novem mestu

franc.brcar@gmail.com

Raziskovalno vprašanje (RV): Kakšna je bila raziskovalna aktivnost na FOŠ v zadnjih letih? Katere raziskovalne metode so bile najpogosteje uporabljene?

Namen: Za fakulteto je raziskovanje velikega pomena. Raziskali smo najpogostejša raziskovalna vprašanja, najpomembnejše teme in raziskovalne metode (kvalitativne, kvantitativne in mešane).

Metoda: Kot raziskovalna metoda je bil uporabljen sistematični pregled opravljenih doktorskih disertacij na fakulteti.

Rezultati: Narejen in prikazan je pregled po spolu, raziskovalnih vprašanjih, temah in raziskovalnih metodah.

Organizacija: Z ugotovitvami bo fakulteta dobila pregled nad raziskovanji v zadnjih letih. To bo v pomoč vodstvu fakultete pri usmerjanju nadaljnjih raziskovanj.

Družba: Fakulteta lahko veliko prispeva pri povečevanju inovativnosti na ravni družbe.

Originalnost: To je prva tovrstna raziskava na fakulteti pa tudi ena redkih na ravni družbe.

Omejitve/nadaljnje raziskovanje: Raziskava je izvirna. Zaradi pomembnosti inovativnosti pa so potrebne še dodatne raziskave.

Ključne besede: izobraževanje, raziskovanje, raziskovalne teme, raziskovalne metode.

Franc Brcar je univerzitetni diplomirani inženir strojništva, magister informacijsko-upravljavskih ved in doktor menedžmenta kakovosti. Dalj časa je bil zaposlen v večjem avtomobilskem podjetju. Na začetku je delal kot specialist na področju operacijskih sistemov in baz podatkov. Sledilo je delo na področju uvajanja in vzdrževanja sistemov za računalniško konstruiranje in ERP rešitev. V zadnjem obdobju se raziskovalno ukvarja z menedžmentom, menedžmentom informacijskih tehnologij, menedžmentom poslovnih procesov, inovativnostjo in kakovostjo. Je predavatelj na več fakultetah na visokošolski, magistrski in doktorski stopnji. Izvaja individualne konzultacije in organizira seminarje za skupine iz statistike (R, SPSS, SAS, Lisrel, ... ), analize kvalitativnih podatkov (ATLAS.ti) in pisanja strokovnih in znanstvenih del (kvalitativne in kvantitativne raziskovalne metode, Word, Excel, PowerPoint, Windows, linux, ... ). 


\section{Systematic Research Review at FOŠ}

Research Question (RQ): What kind of research activities were conducted on FOŠ in the last few years? Which research methodologies were implemented most frequently?

Purpose: Research activities are essential for a higher education institution. This article presents the most common research questions, the most important topics and methodologies (quantitative, qualitative, and mixed methods) in doctoral dissertations.

Method: The systematic research review of successfully defended and completed doctoral dissertations at the Faculty of Organisation Studies (FOŠ) was used as the research methodology.

Results: Results were analyzed and displayed according to gender, research questions, topics, and research methodologies.

Organization: FOŠ will be provided with an overview of the research activities in the last few years. This will help management in directing further research.

Society: FOŠ can contribute a great deal in increasing innovations at society's level.

Originality: This is the first such research at the Faculty of Organisation Studies and one of a few in society.

Limitations / further research: The research is unique. We need additional research on this area, namely because of the importance of innovation.

Keywords: education, research, research topics, research methodologies.

Franc Brcar is a university graduate in engineering (B.Sc. in Engineering), received his Master of Science in Informational and Management sciences (M.Sc.) and his PhD in Quality Management. He has had extensive experience working for a major automobile company. He has worked as a specialist in the field of operational systems and databases as well as worked in the introduction and maintenance of systems for computer construction and ERP solutions. Recently he has been examining management, management of IT systems, management of business processes, and management of innovations and quality.

He is an assistant professor at several faculties at the Bachelor, Masters and PhD level. He is a tutor for research methodology courses, tutor for statistical analysis, conducting workshops on statistical programs (R, SPSS, SAS, Lisrel, ... ), data coding and data analysis (ATLAS.ti), writing scientific and professional research papers and articles (Qualitative and Quantitative Research Methodologies, Word, Excel, PowerPoint, Windows, Linux, ... ). 


\title{
Povezanost med gradniki organizacijske energije in avtopoietičnimi lastnostmi
}

\author{
Mari Božič \\ Fakulteta za organizacijske študije v Novem mestu \\ mari.bozic@gmail.com \\ Annmarie Gorenc Zoran \\ Fakulteta za organizacijske študije v Novem mestu \\ a.zoran@fos-unm.si
}

Raziskovalno vprašanje (RV): Predpostavljamo, da za uresničevanje delavskega soupravljanja potrebujejo sveti delavcev energijo članov sveta delavcev ravno tako, kot organizacije potrebujejo za svoje delovanje energijo, ki jo generirajo zaposleni v procesih ustvarjanja in doseganja ciljev ter medsebojnega sodelovanja na vseh ravneh. $V$ našem temeljnem raziskovalnem vprašanju se sprašujemo, kakšna je povezanost med gradniki organizacijske energije in avtopoietičnimi lastnostmi članov sveta delavcev.

Namen: Namen raziskave je bil preučiti povezanost med gradniki organizacijske energije in avtopoietičnimi lastnostmi članov sveta delavcev, saj predpostavljamo, da se višja stopnja avtopoietičnih lastnosti odraža v višji vrednosti kakovostne organizacijske energije.

Metoda: Za zbiranje informacij za potrebe raziskave smo uporabili metodo anketiranja. Kot merski inštrument smo uporabili vprašalnik, ki smo ga postavili na osnovi izhodišč dveh že oblikovanih vprašalnikov ter predhodno analizirane strokovne literature z našega interesnega področja.

Rezultati: (1) Med avtopoietičnimi lastnostmi in organizacijsko energijo članov sveta delavcev obstaja povezanost. Energiji malodušja in razjedanja se negativno povezujeta z avtopoietičnimi lastnostmi, medtem ko se energiji produktivnosti in udobja pozitivno povezujeta z avtopoietičnimi lastnostmi. (2) Na vse vrste organizacijske energije statistično značilno vpliva avtopoietična lastnost samozavedanje in sicer višje kot je samozavedanje, v manjši meri sta prisotni energiji malodušja in razjedanja ter $v$ večji meri sta prisotni energiji produktivnosti in udobja.

Organizacija: Na osnovi izsledkov raziskave smo potrdili lastnosti članov sveta delavcev, ki prispevajo k ustvarjanju kakovostne organizacijske energije. Krepitev teh lastnosti posameznika lahko pripomore $k$ njegovemu proaktivnemu pristopu $k$ uresničevanju delavskega soupravljanja. 
Družba: Prispevek družbi so pojasnjena spoznanja o vplivih avtopoietičnih lastnosti članov svetov delavcev na njihovo organizacijsko energijo.

Originalnost: Izvedena raziskava predstavlja prispevek k novim spoznanjem, ki bi lahko prispevala k proaktivnemu uresničevanju delavskega soupravljanja $v$ organizacijah.

Omejitve/nadaljnje raziskovanje: $V$ raziskavi smo proučevali vpliv avtopoietičnih lastnosti članov sveta delavcev na njihovo organizacijsko energijo. Na organizacijsko energijo članov sveta delavcev pa lahko vplivajo tudi drugi dejavniki, ki bi jih lahko preučevali z nadaljnjimi raziskavami.

Ključne besede: organizacija, delavsko soupravljanje, svet delavcev, člani sveta delavcev, avtopoietične lastnosti, organizacijska energija.

Mari Božič je diplomirana ekonomistka, specialistka poslovne ekonomije in magistrica znanosti s področja menedžmenta. Razpolaga s tehničnim znanjem s področja kemijske dejavnosti, ki ga pridobila $v$ srednji kemijski šoli. Nadgradila ga je z izkušnjami, ki jih je pridobila z vodenjem zaposlenih in organizacijo dela tako na področju proizvodnje kot tudi razvoja in raziskav. Je članica sveta delavcev in certificirana notranja presojevalka sistema vodenja kakovosti. Njeno raziskovalno zanimanje se nanaša na zaposlene, njihove avtopoietične lastnosti in organizacijsko energijo ter na medsebojne odnose v organizaciji. Na Fakulteti za organizacijske študije pripravlja doktorsko disertacijo s področja delavskega soupravljanja v slovenskih organizacijah. Sodeluje na strokovnih konferencah in objavlja članke $v$ domačih publikacijah.

Annmarie Gorenc Zoran je redna profesorica na Fakulteti za organizacijske študije v Novem mestu, poučuje tudi na daljavo v Sloveniji in v tujini. Njen raziskovalni interes je interdisciplinarni pristop do komunikacije kot kanala za e-izobraževanje, je okvir za nenehno izboljševanje v smislu povratnih informacij o standardih kakovosti, orodje $v$ izobraževanju in poučevanju, analitični okvir pri raziskovanju in prispevek k organizacijski znanosti. Za revijo Izzivi prihodnosti je urednica ter opravlja delo recenzentke $v$ mednarodnih indeksiranih revijah. Aktivno deluje tudi na področju evalvacije kakovosti v visokem šolstvu. Objavila je poglavja v knjigah, številne članke ter jih predstavila na mednarodnih, nacionalnih in regionalnih konferencah.

\section{The Connection between the Building Blocks of Organizational Energy and Autopoietic Endowments}

Research Question (RQ): We assumed that to achieve labour co-management or Workers' Participation, Works Councils need the energy of the Works Council members just as organisations need the energy generated by employees in the processes of creating and achieving their goals and working together at all levels. Our overarching research question 
examined the connection between the building blocks of Organisational Energy and the Autopoietic Endowments of Works Council members.

Purpose: The purpose of the research was to examine the relationship between the building blocks of Organizational Energy and the Autopoietic Endowments of Works Council members. We assumed that a higher level of Autopoietic Endowments is reflected in a higher value of quality Organizational Energy.

Method: We used quantitative analysis using a survey tool as our measuring tool. The questionnaires were based on two existing questionnaires and modified based on scholarly literature in our field of interest.

Results: (1) There is a connection between Autopoietic Endowments and Organisational Energy of Works Council members. Resigned Inertia and Corrosive Energy were negatively associated with Autopoietic Endowments, while Productive Energy and Comfortable Energy were positively associated with Autopoietic Endowments. (2) All types of Organisational Energy were statistically significantly influenced by the Autopoietic Endowments of SelfAwareness, namely the higher that Self-Awareness is, to a lesser extent were Resigned Inertia and Corrosive Energy present. In contrast, Productive Energy and Comfortable Energy were presented to a greater extent.

Organisation: Based on the research results, we confirmed the endowments of Works Council members that contribute to the creation of quality Organizational Energy. Strengthening these endowments can contribute to a proactive approach to the realisation of Workers' Participation.

Society: The contribution to society is explained by the findings on the Autopoietic Endowments of Works Council members' influences on their Organizational Energy.

Originality: The conducted research represents a contribution to new findings that could contribute to the proactive implementation of Workers' Participation in organisations.

Limitations / further research: We studied only the influence of Autopoietic Endowments of Works Council members on their Organisational Energy. The Organisational Energy of Works Council members can also be influenced by other factors, which could be studied further.

Keywords: Organisation, Workers' Participation, Works Council, Works Council members, Autopoietic Endowments, Organisational Energy. 
Mari Bozic holds a Bachelor of Science in Economics, a Bachelor of Science in Business Economics, and a Master of Science in Management. She has technical knowledge in the field of chemical activity, which she acquired during her SOK level 5 chemistry class. She has advanced her knowledge with experience that she has gained in managing employees and organising work in both manufacturing and research and development. She is member of the Works Council and an internal auditor of the quality system. Her research interest is related to employees, their autopoietic endowments and organisational energy, and to relationships within the organisation. At the Faculty of Organizational Studies, she is preparing a doctoral dissertation from the area of workers' participation in Slovenian organisations. She participates in professional and scientific conferences and publishes articles in scholarly publications.

Annmarie Gorenc Zoran is a Professor at the Faculty of Organisation Studies in Novo mesto as well as teaches distance learning courses in Slovenia and abroad. Her research interest is an interdisciplinary approach to communication, as a channel in e-learning, a framework for continuous improvement in terms of quality standards feedback, a tool in education and teaching, as an analytical framework to research, and a contribution to management. She is the editor of the journal Challenges of the Future and is an active peer reviewer for international indexed journals. She is also active in evaluating quality in higher education. She has published book chapters, numerous articles, and presented at international, national, and regional conferences. 


\section{Vpliv dinamičnega poslovnega okolja na temeljno strategijo podjetja}

\section{Sabina Veršič}

Fakulteta za organizacijske študije v Novem mestu

sabina.versic@fos-unm.si

Raziskovalno vprašanje (RV): Kakšna je vloga dinamičnega poslovnega okolja na izbiro temeljne strategije podjetja?

Namen: Raziskati vpliv dinamičnega poslovnega okolja na izbiro temeljne strategije podjetja. Torej kakšen vpliv ima nepredvidljivost okolja podjetja na oblikovanje in izbiro temeljne strategije podjetja.

Metoda: Pričujoč članek temelji na kvalitativni raziskavi, imenovani sistematičen pregled literature. S pomočjo sistematičnega pregleda literature smo prikazali pregled obstoječih raziskav na obravnavanem področju in področja, ki so primerna za nadaljnje raziskovanje.

Rezultati: Ugotovljeno je bilo, da članek prikazuje možnosti nadaljnjega raziskovanja na obravnavanem področju. Prikazana je vloga in vpliv dinamičnega okolja podjetja pri oblikovanju in izbiri temeljne strategije podjetja.

Organizacija: Rezultati članka prikazujejo možnosti nadaljnjega raziskovanja na obravnavanem področju. Ugotavljamo, da je na obravnavanem področju mnogo raziskav, ki se nanašajo na vpliv posameznih vidikov okolja podjetja na strategije podjetja, vendar v teh raziskavah ni upoštevan celovit vpliv nepredvidljivosti okolja podjetja. Tako pričujoča raziskava prikazuje pomen sinergije med vidiki dinamičnega okolja podjetja in temeljno strategijo podjetja, ki je pomembna za doseganje rasti in razvoja podjetja.

Družba: $V$ članku je prikazano, da morajo podjetja za uresničevanje temeljne strategije podjetja, pri sprejemanju strateških poslovnih odločitev upoštevati različne vidike okolja podjetja (ekološko okolje, družbeno-socialno okolje, ekonomsko okolje, tehnično-tehnološko okolje, politično-pravno okolje idr.).

Originalnost: $\vee$ znanstveno-raziskovalni literaturi smo zasledili mnogo raziskav vezanih na vpliv strategij podjetja na uspešnost, rast in razvoj podjetja. Nismo pa našli raziskav, ki bi pri tem celovito upoštevale vpliv dejavnikov, ki izhajajo iz okolja podjetja in se vsebinsko omejile na temeljno strategijo podjetja.

Omejitve/nadaljnje raziskovanje: Pričujoča raziskava predstavlja članek in temelji na pregledu znanstveno-raziskovalne literature iz obravnavanega področja. $V$ prihodnje predlagamo kvantitativno raziskavo, ki bi prikazala vpliv dinamičnega poslovnega okolja podjetja na izbiro temeljne strategije podjetja. 
Ključne besede: menedžment, strateški menedžment, strateško planiranje, temeljna strategija, nepredvidljivost, poslovno okolje.

Sabina Veršič se je po končanem dodiplomskem in podiplomskem študiju na Ekonomsko-poslovni fakulteti Univerze v Mariboru, leta 2016 vpisala na doktorski študij na Ekonomsko-poslovni fakulteti Univerze v Mariboru. Raziskuje področje strateškega menedžmenta in politiko podjetja. Je mlada raziskovalka na Fakulteti za organizacijske študije v Novem mestu.

\section{The Impact of Dynamic Environment on Basic Company Strategy}

Research Question (RQ): What is the role of a dynamic business environment in choosing the company's core strategy?

Purpose: Explore the impact of a dynamic business environment on the choice of the company's basic strategy. However, what impact does the unpredictability of the company's environment has on the design and choice of the company's basic strategy.

Method: We made qualitative research, namely the study of a scientific literature. The emphasis is on research by foreign authors.

Results: Scientific paper shows the possibilities for further research. It shows the role and impact of the company's dynamic environment in designing and choosing the company's basic strategy.

Organization: The results of an article show the possibilities of further research in the field under examination. We found that there is a lot of research in the field under consideration relating to the impact of individual aspects of the company's environment on the company's strategies, but these surveys do not consider the overall impact of the unpredictability of the company's environment. Thus, this research shows the importance of synergy between aspects of the company's dynamic environment and the company's basic strategy, which is important for achieving the growth and development of the company.

Society: The results of an article show that for the implementation of company's core strategy, companies have to consider different aspects of the company's environment (ecological environment, social environment, economic environment, technical and technological environment, political and legal environment, etc.) when making strategic business decisions. Originality: In the scientific and research literature we have found a lot of research related to the impact of the company's strategies on the performance, growth and development of the 
company. However, we did not find research that would consider factors arising from the company's environment.

Limitations/Future Research: This study presents a scientific paper that is based on a review of scientific research literature in the field under consideration. In the future, we propose quantitative research to demonstrate the impact of the company's business environment on the choice of the company's basic strategy.

Keywords: management, strategic management, strategic planning, basic strategy, unpredictability, business environment.

Sabina Veršič after finishing undergraduate and postgraduate studies at the Faculty of Economics and Business, University of Maribor, enrolled in doctoral studies in 2016 at the Faculty of Economics and Business, University of Maribor. Her research interest is mainly focused on the field of strategic management and company policy. She is a research assistant at the Faculty of Organisation Studies in Novo mesto. 


\title{
Napoved vrednosti trga obstoječih in prihajajočih tehnoloških sprememb
}

\section{Tine Bertoncel}

\author{
Fakulteta za organizacijske študije v Novem mestu
}

tine.bertoncel@gmail.com

Maja Meško

Univerza na Primorskem, Fakulteta za management, Koper

mirko.markic@guest.arnes.si

Raziskovalno vprašanje (RV): Kakšne so napovedi za vrednost trga novodobnih tehnologij?

Namen: Članek se osredotoča na predstavitev napovedi za trg povezan s tehnološkim razvojem.

Metoda: Za namene raziskave smo pregledali trende pri razvoju programske in strojne opreme (kibernetsko fizični sistemi, internet stvari, umetna inteligenca itd.). Pregledali smo tudi alternativne tehnologije, ki imajo potencial, da zamenjajo trenutno tehnologijo ali pa povečajo njeno učinkovitost (kvantno računanje, nevromorfični harver itd.)

Rezultati: Pregled literature je pokazal, da se bo trg starih in novih tehnologij močno povečal, v nekaterih primerih eksponentno. Posamezne tehnologije bodo vplivale na razvoj preostalih tehnologij, kar bo imelo sinergijski efekt pri sočasni uporabi tehnologij, kot tudi za trg omenjenih tehnologij.

Organizacija: Če se kvantno računanje in neuromorfična strojna oprema pokažeta kot neizvedljiva, bo to pomenilo, da je napredek v razvoju naših tehnologij omejen, vsaj do trenutka, ko se bodo odkrile nove tehnologije. Nove tehnologije, s sinergijskim efektom, bodo lahk omejitev trenutnih tehnologij zmanjšale čez čas.

Družba: Po drugi strani pa je neizvedljivost kvantnega računanja in nevromorfične strojne opreme slaba za Industrijo 4.0, saj je trenutna vrednost Industrije 4.0 71.7\$ miljard dolarjev in se pričakuje, da se bo ta vrednost povečala na 156.6\$ miljard dolarjev do leta 2024.

Originalnost: $\mathrm{Na}$ to temo še ni bilo posodobljenega pregleda trenutnega stanja trga za vse obstoječe in prihajajoče tehnologije.

Omejitve/nadaljnje raziskovanje: Omejitev, ki se pojavi pri raziskavi je ta, da se okolje stalno spreminja in lahko da bodo $v$ naslednih letih naše napovedi zastarele ali pa posodobljene, kot tudi to, da je tema zelo kompleksna in je iz tega razloga težko napovedati prihodnost. 
Ključne besede: tehnologije Industrije 4.0, kvantno računanje, neuromorfična strojna oprema, Moorjev zakon.

\footnotetext{
$* * *$

Dr. Tine Bertoncel je doktor znanosti na področju managementa. Dela kot raziskovalec na Fakulteti za organizacijske študije v Novem mestu, kjer raziskuje področja Industrije 4.0, menedžmenta, sistemov zgodnjega obveščanja in rudarjenja besedil. Je avtor in soavtor večih znanstvenih in strokovnih člankov.).
}

Dr. Maja Meško je redna profesorica managementa na Fakulteti za management Univerze na Primorskem. Doktorirala je na področju kineziologije, naslov njene doktorske disertacije je Definiranje nekaterih gibalnih sposobnosti in psiholoških značilnosti slovenskih vojaških pilotov. Njeni raziskovalni interesi obsegajo področja managementa, psihologije v managementu, zdravja na delovnem mestu ter vodenja. Sodelovala je in še sodeluje tudi pri različnih projektih. Je avtorica in soavtorica številnih znanstvenih in strokovnih člankov.

\section{Prediction of Market Value for Current and Future Technological Developments}

Research Question (RQ): What are the predicted market trends in current and upcoming technological developments?

Purpose: This article tries to find out how the market will grow in regards to advanced technologies have already been developed for some time and those that are in their early phases of development.

Method: For the purpose of the study trends in market research were looked. We studied the current hardware and software market prices and the current market value of several different technologies (Cyber-physical systems, Traditional hardware and software, Artificial Intelligence etc.). Finally, we looked at the market trends of alternative technologies (Quatum computing, neuromorphic hardware etc.)

Results: We found that the market for all of the major technological developments, now and in the future, is expected to increasingly grow, in some cases at exponential rates. Overall, it seems that each individual technology will contribute to the growth of other specificied technologies, as they can be used to increase the efficiency of other technologies, as well as to have a synergistic effect, which in turn contributes to the technology's market value.

Organization: If quantum computing or neuromorphic hardware do not end up being viable additions to or alternatives to current technology, Industry 4.0 reaches a dead end, which means that there is a limit to how advanced software and hardware in smart manufacturing can become. However, the limit due to the synergistic effects of various technologies, is likely still a long way ahead of us. 
Society: For those that are afraid of technological development, smart manufacturing technologies reaching their limit might be seen as a positive outcome, however for an industry that is currently valued at approximately $71.7 \$$ billion dollars and is expected to grow to 156.6 billion dollars by 2024, this is not a great thing to hear. However, it seems that new technologies are emerging at just the right time for Industrial managers to not worry.

Originality: To the best of our knowledge, this kind of literature review has not yet been conducted on up-to-date market value of tehnologies.

Limitations / further research: The limitation that arises is that the environment in which technology arises is constantly changing, within a few years these predictions might be outdated or updated, as well as the topic, is very complex and hard to predict.

Keywords: Industry 4.0 technology, Quantum computing, Neuromorphic hardware, Moore's law.

Tine Bertoncel received his PhD in management. He is a research assistant at the Faculty of organization studies, where he is doing research on Industy 4.0, management, early management systems and text mining. He authored or co-authored various scientific papers published in professional and academic journals.

Maja Meško is a full professor of management at the Faculty of Management, University of Primorska. She received $\mathrm{PhD}$ in kinesiology, the title of her doctoral dissertation is Defining certain motor abilities and psychological characteristics of the Slovenian military pilots. Her research interests include the areas of management, psychology in management, occupational health and management. She has also participated in various projects. She authored or co-authored various scientific papers published in professional and academic journals. 


\section{Založniška dejavnost \\ Fakultete za organizacijske študije v Novem mestu \\ I Z D A N E M O NOG RA F I J E}

1. Ranljivosti programske opreme

Dobrovoljc, Andrej

2. Sistemska dinamika

Turnšek, Tit

2020

3. Družba 5.0: Izzivi prihodnosti

Bertoncel, Tine

2020

4. Gradniki novih organizacijskih modelov Gorenc Zoran, Annmarie et al.

2020

5. Vodenje in pripadnost $v$ osnovni šoli

Plešnik, Janko; Bukovec, Boris

2020

6. Poslovna matematike (e-knjiga)

Usenik, Janez; Vidiček, Matija

7. Poslovna statistika (e-knjiga)

Usenik, Janez; Vidiček, Matija

2020

2020

8. Izbrana poglavja iz matematike (e-knjiga)

Usenik, Janez

2020

9. Vpliv uporabe orodij managerjev na ekonomsko donosnost Markič, Mirko; Kreslin, Damijan

10. Delovni terapevt $v$ inkluzivni šoli: Trenutno stanje in smernice Šuc, Lea

11. Zrna odličnosti FOŠ: nove paradigme organizacijskih teorij 2018 Bukovec, Boris (ur.)

12. Zrna odličnosti FOŠ: nove paradigme organizacijskih teorij 2017 Bukovec, Boris (ur.)

13. Značilnosti sistemov vodenja kakovosti v slovenskih organizacijah in njihov vpliv na poslovno uspešnost organizacij

Vinko Bogataj; Gordana Žurga; Adolf Šostar

14. Menedžment kakovosti in odličnost zdravnikov v javnem zdravstvu Rumpf, Dean; Voga, Gorazd; Meško Štok, Zlatka

15. Sistemi vodenja kakovosti in modeli odličnosti: ključni dejavniki (ne)uspešnega delovanja (e-knjiga)

Škafar, Branko

16. Temelji avtopoieze v orgaizaciji: Avtopoietska 4.0 (r)evolucija človeka Balažič Peček, Tanja; Bukovec, Boris

17. Management varnosti pri delu, delovne razmere in gospodarska učinkovitost (e-knjiga)

Pavlič, Miran, Markič, Mirko

18. Kvalitativno raziskovanje koncepta avtopoieze $\mathbf{v}$ organizaciji (e-knjiga) Balažic Peček, Tanja

19. Podlage in metode za raziskovanje in projektiranje organizacije Ivanko, Štefan

20. Celostna obravnava dolgotrajne oskrbe v Sloveniji

Kavšek, Marta; Bogataj, David 
21. Sodelovalno mreženje in izraba inovacijskega potenciala $v$ turističnem prostoru

Colarič-Jakše, Lea-Marija

22. Model McKinsey 7-S kot kazalnik odličnosti organizacije

Kalan, Mateja; Meško, Maja

23. Nova doktrina organizacije - 2.del: Preusmeritev pozornosti

Ovsenik, Jožef; Ovsenik, Marija

24. Avtopoietska organizacija Bukovec, Boris (ur.)

25. Kakovost v slovenski javni upravi: Delovanje Odbora za kakovost 1999-2012

Žurga, Gordana

2017

26. Poslovne vrednote mladih v Sloveniji

Pinterič, Uroš

2016

27. Selected topics in modern society (e-knjiga)

Kaplánová, Patrícia

2016

28. Glocalisation of the crisis: could Slovenia survive economic crisis better? (e-knjiga)

Pinterič, Uroš

29. Zrna odličnosti FOš: nove paradigme organizacijskih teorij 2016 Bukovec, Boris (ur.)

30. Pisanje strokovnih in znanstvenih del

Brcar, Franc

31. Education policy as the factor of development (e-knjiga)

Pinterič, Uroš

32. Spregledane pasti informacijske družbe

Pinterič, Uroš

33. Psihosocialni dejavniki tveganja za bolečino v križu pri slovenskih poklicnih voznikih in absentizem

Kresal, Friderika; Meško, Maja

34. Zgodovina organizacijske misli Ivanko, Štefan

35. Karierno načrtovanje: kako najti v sebi skriti zaklad?

Turnšek Mikačić, Marija; Ovsenik, Marija

36. Sodobni trendi v turizmu

Ovsenik, Rok

37. Selected topics in change management (e-knjiga)

Kaplánová, Patrícia (ur.); Pinterič, Uroš (ur.)

38. Political legacy and youth civic engagement in Slovakia Mihálik, Jaroslav

39. Turistični prostori različnosti: turizem, turisti in fotografska podoba Ambrož, Milan; Bukovec, Boris

40. Izobraževanje za furizem v Sloveniji

Ovsenik, Rok; Bukovec, Boris; Ovsenik, Marija

41. Zrna odličnosti FOŠ: nove paradigme organizacijskih teorij 2015

Bukovec, Boris (ur.)

42. Kontrolna teorija sistemov: model za sistemsko razmišljanje v sistemu zdravstvenega varstva

Mlakar, Tatjana

43. Featuring Norden in ten episodes

Czarny, Ryszard M. 
44. Sociológia mládeže Macháček, Ladislav

45. Inter-municipal cooperation in Slovakia : the case of regions with highly fragmented municipal structure

Klimovsky, Daniel

46. Rethinking public policies (e-izdaja)

Pinterič, Uroš

47. Local Governance between democracy and efficiency Jüptner, Petr. (et al.)

48. Pasti razumevanja politične realnosti : pregled konceptov sodobnega političnega sistema

Pinterič, Uroš

49. Selected issues of administrative reality

Pinterič, Uroš; Prijon, Lea

50. Organizacijske paradigme: podlage za nastanek in razvoj organizacijskih teorij Ivanko, Štefan 


\section{Z N A N S T VEN I REVIJI F O S}

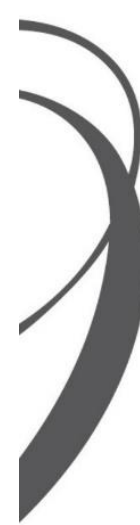

\section{RUO}

Revija za

univerzalno

odličnost

Journal of Universal Excellence

Letnik x. številka x. mesec zoxx
Revija za univerzalno odličnost (Journal of Univesal Excellence)

je interdisciplinarna revija, ki združuje organizacijske vede oz. menedžment in univerzalno odličnost, $t \mathrm{j}$. poslovno, organizacijsko in osebno odličnost.

\section{$\bar{F} \overline{\text { Fos }} \equiv$}

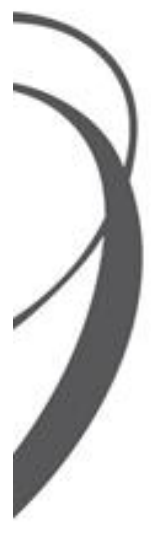

\section{Izzivi prihodnosti}

(Challenges of the Future)

je znanstvena revija, ki poskuša odgovarjati na ključna vprašanja družbene teme pri čemer akademsko rigoroznost nadgrajuje $\mathrm{z}$ inovativnostjo $\mathrm{v}$ tematikah in pristopu. 
RAZ VIJAMO

USTVARJALNE

POTENCIALE

POSAMEZNIKOV IN

OR G A N I Z A CI JSKE

ZNANOSTI

TER PRISPEVAMO K

NENEHNEMU

IZBOLJŠEVANJU

KAKOVOST I

ŽIVLJENJA.

ŠTUDIJSKI PROGRAMI MENEDŽMENT KAKOVOSTI

- VISOKOŠOLSKI

- MAGISTRSKI

- DOKTORSKI

www.fos-unm.si info@fos-nnm.si

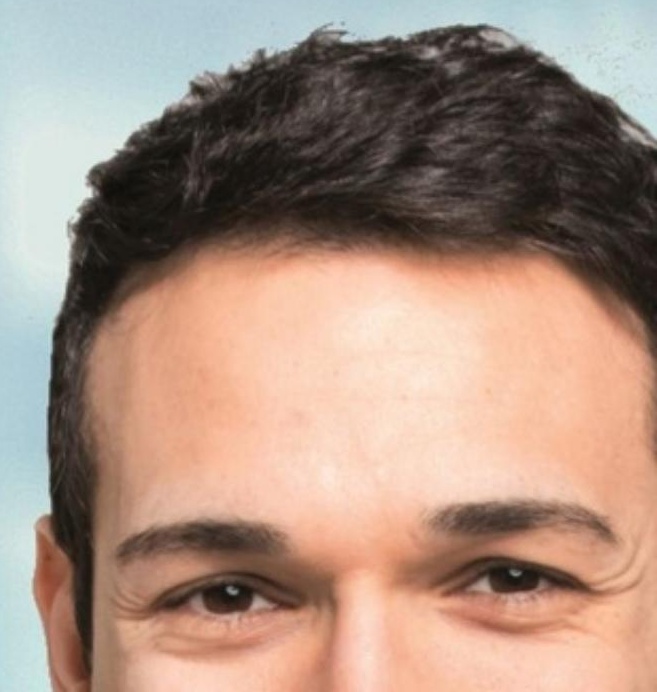

